\title{
Strategiczny instrument czy instytucja społeczna? Zracjonalizowane mity uniwersytetu w percepcjach interesariuszy reform szkolnictwa wyższego w Polsce
}

\begin{abstract}
STRESZCZENIE: Europejskie uniwersytety znalazły się pod presją reform, których celem jest uczynienie z nich instrumentów rozwoju społecznego i gospodarczego przy jednoczesnym zniesieniu statusu uczelni wyższych jako instytucji buforowanych społecznie. Celem artykułu jest zbadanie hipotezy, że napięcia i niekonsekwencje w dotychczasowych reformach szkolnictwa wyższego w Polsce mają swoje źródła w podstawowym konflikcie między instytucjonalną a instrumentalną wizją uczelni wyższej. Wyniki badań wskazują na przecinanie się „zracjonalizowanych mitów”, które zamykają sektor szkolnictwa wyższego w „gorsecie” odbieranym przez interesariuszy bardziej jako powrót do komunistycznej przeszłości niż droga ku lepszej przyszłości. Wyniki te, rozpatrywane z punktu widzenia teorii systemów drugiej fali, podważają założenie, iż historyczna instytucja uniwersytetu może zostać przekształcona w instrument służący realizacji priorytetów państwa dzięki zrównoważonej polityce nagród i kar.
\end{abstract}

SŁOWA KLUCZOWE: polityka edukacyjna, reformy edukacyjne, europejskie uniwersytety, autonomia uniwersytetu, zarządzanie w szkolnictwie wyższym, autopoiesis, teoria systemowa

\section{Wprowadzenie}

W sytuacji, gdy ponad 60\% absolwentów szkół średnich w Europie kontynuuje naukę na uczelniach wyższych (World Bank 2017), nie ma w zasadzie europejskiej rodziny, której przyszłość nie byłaby w pewnym stopniu zależna od losów uniwersytetów i ich instytucjonalnych kuzynów bądź potomków. Od lat 60. XX w., wraz z rosnącą falą umasowienia nauki, uczelnie wyższe stały się centralnym elementem wpływającym nie tylko na przyszłość jednostek, lecz także na społeczny i gospodarczy rozwój, zyskując miano „najważniejszych instytucji w społeczeństwie ludzkim” (Marginson et al. 2018, tłum. własne). Zarówno rządy, jak i opinia publiczna w Unii Europejskiej postrzegają uniwersytety jako ,jedne z nielicznych instytucji, które mogą pomóc 
Europie wyjść z panującego w niej obecnie wielowymiarowego kryzysu" (Gornitzka i Maassen 2017, tłum. własne). Unijni decydenci próbują - w sposób zgodny z podejściem do organizacji jako systemów otwartych, reagujących na zmiany w otaczającym je środowisku - wykorzystywać zarówno nagrody, jak i sankcje, aby motywować uniwersytety do kształcenia absolwentów, którzy odnajdą się na rynku pracy oraz dotworzenia rynkowych innowacji.

W efekcie instytucje, które historycznie funkcjonowały jako niezależne stowarzyszenia mistrzów i studentów, chronione przed społecznymi i ekonomicznymi naciskami (Shaw i Lenartowicz 2016), są obecnie zalewane próbami reform dążących do przekształcenia ich w silniki narodowego i globalnego rozwoju (Maassen i Olsen 2007). W całej Europie inicjatywy w zakresie reform szkolnictwa wyższego odzwierciedlają raczej instrumentalną wizję uniwersytetów, które - zgodnie z logiką reformatorów - powinny przestać izolować się od przemysłu i społeczeństwa i stać się ,instrumentami zmian w politykach krajowych” (Olsen 2007: 30; Kwiek 2015: 79, tłum. własne). Takie podejście stoi w otwartej sprzeczności z instytucjonalną wizją uniwersytetu wywodzącą się ze średniowiecza, w której „rządząca się stałymi zasadami społeczność uczonych” (Olsen 2007: 30, tłum. własne), chroniona przez państwo przed koniecznością angażowania się w krótkoterminowe interesy różnych grup społecznych, zdobywa i rozpowszechnia racjonalnie udowodnioną wiedzę. Ramirez i Tiplic (2014) opisują kulturową zmianę, jakiej doświadczają obecnie uniwersytety w Europie jako napędzaną ,triumfem modeli uniwersytetu jako społecznie uwarunkowanej, zracjonalizowanej organizacji” w przeciwieństwie do podejścia traktującego uczelnie wyższe jako „społecznie buforowane instytucje o historycznych korzeniach" (s. 440, tłum. własne).

Obecna zmiana podejścia nie obyła się bez kontrowersji, ponieważ „społeczne nieuwikłanie" (social disembeddedness) jest jakością definiującą europejski uniwersytet od jego powstania (Krucken 2003: 324). Delikatny taniec niezależności i odpowiedzialności jest najbardziej widoczny w postkomunistycznych krajach Europy Centralnej i Wschodniej, gdzie pojęcie szkolnictwa wyższego jako „instrumentu zmiany kierunku polityki narodowej" (Olsen 2007: 30) przywołuje przede wszystkim wspomnienia silnej interwencji państwa w wewnętrzne funkcjonowanie uniwersytetów w epoce komunizmu. Do dziś nie zbadano empirycznie, w jaki sposób międzynarodowe trendy obecne w reformach szkolnictwa wyższego przecinają się z organizacyjną tożsamością uczelni wyższych w krajach o ustalonych tradycjach akademickich, gdzie uniwersytety służyły jako kluczowe instrumenty „projektu socjalistycznej modernizacji państwa” (Peteri 2000: 280, tłum własne).

Studium przypadku Polski okazuje się szczególnie interesujące, jako że w okresie realnego socjalizmu większość aspektów polskiego systemu szkolnictwa wyższego było sterowanych centralnie (Zysiak 2016) - a mimo to społeczne bufory wokół 
uniwersytetów pozwoliły zachować wysepki akademickiej wolności na wzór przedwojennej koncepcji uniwersytetu jako samorządnej społeczności ludzi nauki (Simonova i Antonowicz 2006). Po odzyskaniu przez kraj niepodległości uniwersytety zyskały rozległą autonomię i wróciły do modelu akademickiej samorządności, ugruntowując instytucjonalną wizję uczelni wyższych poprzez skojarzenie narodowego i akademickiego samostanowienia (Shaw 2018).

Nieprzypadkowo, nawet po próbach przesunięcia przez polskie rządy ram prawnych w stronę wzorca instrumentalnego za pomocą dwóch reform w latach 20102011 i 2018-2019, polskie szkolnictwo wyższe pozostaje jednym z europejskich bastionów modelu zarządzania utrzymującego tradycyjny wzorzec „społeczności uczonych kierującej się zasadami” (Kwiek 2015; Shaw 2018). Kwiek (2015) postawił na łamach niniejszego czasopisma hipotezę, że napięcie obserwowane w Polce może wynikać z „konfliktu między instytucjonalną wizją uniwersytetu podzielaną przez społeczność akademicką („społeczność naukowców” opierającą się na wartościach) z instrumentalną wizją wyznawaną przez społeczność osób decyzyjnych („organizacja" nastawiona na realizację celów, napędzana czynnikami z zewnątrz)" - konfliktu, który jest tak naprawdę konfliktem „fundamentalnych wartości” (s. 87). Niniejsze badania były próbą empirycznego sprawdzenia hipotezy Kwieka (2015).

Ramy teoretyczne zastosowane w tym badaniu czerpią z teorii systemowej drugiej fali, która traktuje organizacje ludzkie jako złożone i żyjące systemy podlegające procesowi autopoiesis, czyli nieustannego, cyklicznego, samodzielnego odtwarzania się, regulującego wszystkie czynności systemu (Luhmann 2009). Podczas gdy Kwiek (2015) zakłada, że istnieje różnica w fundamentalnych wartościach wyznawanych przez aktorów-członków owych dwóch różnych społeczności, podejście systemowe sugeruje zbadanie wzorca lub wzorców określających sposób, w jaki system(y) akademickie samoorganizują się w obliczu obecnej, zewnętrznej presji wprowadzania zmian. Z perspektywy systemowej wymiana między systemem akademickim a jego otoczeniem zachodzi zgodnie z własnym wzorcem tożsamości konstruowanym poprzez język - przywołując obraz z obszaru biologii, według zapisu „DNA” regulującego samodzielne odtwarzanie się systemu (Lenartowicz 2015). Kierując się tymi założeniami, autorka postawiła sobie za cel zidentyfikować dystynkcje składające się na trwałe wzorce organizacyjnej tożsamości różnego typu uczelni publicznych przejawiające się w narracjach kluczowych aktorów zmian w okresie, gdy uczelnie te stały się adresatami zarówno nakazów, jak i zachęt, które miały w zamierzeniu swoich twórców pobudzać do zmiany. W tym celu przebadano metafory i zracjonalizowane mity przywoływane na poparcie fundamentalnych wartości uznawanych przez głównych graczy w systemie szkolnictwa wyższego za kluczowe dla charakteru uniwersytetu.

Niniejsza praca analizuje reformy polskiego systemu szkolnictwa wyższego z perspektywy dwóch grup o największym wpływie na jego kształt - architektów reform 
z lat 2010/2011, które wprowadzily „zupełnie nowe zasady gry” zgodne z europejskim wzorcem, oraz przywódcami instytucji akademickich, którym przyszło wprowadzać te reformy w życie. Autorka porównuje ich percepcje reform i „zracjonalizowane mity” przywoływane wich postrzeganiu sensu zachodzących zmian. Autorka eksploruje również możliwe trajektorie przyszłych zmian oraz wyzwania, jakie mogą pojawić się w procesie pozycjonowania uniwersytetów jako silników rozwoju gospodarczego i społecznego.

\section{Ramy teoretyczne}

W ciągu ostatnich dziesięciu lat wspólnota europejska wprowadziła regulacje oparte na założeniu, że przy odpowiednim połączeniu nakazów prawnych ze sporymi zastrzykami zewnętrznych inwestycji będzie można nauczyć społeczność akademicką, jak kształcić absolwentów, którzy odnajdą się na rynku pracy, oraz tworzyć rynkowe innowacje. To podejście było zgodne z rozumieniem organizacji jako otwartych systemów zależnych od środowiska, które jest dla nich źródłem informacji i zasobów (np. Von Bertalanffy 1968). Perspektywa systemów otwartych, ujmująca zmianę w organizacji jako efekt zmiany zachodzącej w środowisku, została upowszechniona w praktyce zarządzania przez Katza i Kahna (1966), służąc jako koncepcyjna podstawa interwencji organów publicznych w zmianę sposobu finansowania niezależnych organizacji. Jednak wczesna teoria systemów nie sprawdziła się w przypadku mechanizmów wywoływania i podtrzymywania takiej zmiany, ani nie dostarczyła koncepcyjnie spójnych podstaw oceny takich zewnętrznych interwencji (Lenartowicz 2018).

Wyzwanie to, podjęte przez teoretyków systemowych drugiej fali, spowodowało znaczący przełom wynikający z Luhmanowskiego ujmowania organizacji jako systemów autopoetycznych. Pojęcie autopoiesis, zastosowane pierwotnie w biologii, odnosi się do samoodtwarzania się systemów w oparciu o ich własny wzorzec tożsamości. Luhmann (2009) twierdzil, że podczas gdy systemy biologiczne utrzymują się dzięki procesom materialnym, systemy społeczne trwają dzięki środkom komunikacji. Tak jak komunikacja komórki z otoczeniem odbywa się zgodnie z jej własnym „harmonogramem” zakodowanym w jej DNA, tak samo interakcje między organizacją a jej ekosystemem wynikają z woli przetrwania organizacji, tzn. obejmują to, co organizacja postrzega jako niezbędne do tworzenia własnego wzorca tożsamości. Z tego względu zmiana w otoczeniu wywoła zmianę w autopoetycznym systemie społecznym jedynie w takim zakresie, w jakim zostanie uznana za ważną dla własnego samotworzenia. Zewnętrzne bodźce nieistotne dla systemowego wzorca tożsamości, lecz niemożliwe do zignorowania, będą traktowane jako „perturbacje” i łagodzone „kompensacjami” - zachowaniami mającymi na celu przywrócenie zdolności systemu do przetrwania. Seidl (2016) sugeruje, że trwała zmiana organizacyjna to taka, która zmienia wzorzec tożsamości systemu (s. 113). Lenartowicz (2018) twierdzi, że jedyna 
zmiana warta inwestowania środków publicznych to nie zmiana obejmująca jedynie powierzchowne praktyki, lecz taka, która zmieni wzorzec tożsamości zakorzeniony $\mathrm{w}$ codziennym, dyskursywnym autoopisie organizacji.

Panuje dość powszechne przekonanie, że konceptualizacja systemów społecznych jako autopoetycznych to ogromny kamień milowy w rozwoju teorii organizacji. Magalhaes i Sanchez (2009) posunęli się nawet do stwierdzenia, że takie podejście może się stać nową ramą spajającą nauki o organizacji. Niniejszy artykuł jest próbą praktycznego zastosowania autopoetycznej konceptualizacji do sprawdzenia hipotezy Kwieka (2015) o konflikcie fundamentalnych wartości w polskim systemie szkolnictwa wyższego. Jeżeli taki konflikt ma miejsce, jak rozłożone są jego linie i co ważniejsze, czy zbiegają się z granicami wyraźnie odmiennych systemów organizacyjnych, które mają różne wzory tożsamości? Czy naciski, aby ulepszać zewnętrzną adekwatność, postrzegane są jako spójne lub niespójne z tożsamościami różnych typów instytucji publicznych zajmujących się kształceniem na poziomie wyższym? Czy istnieją dowody zmian wynikających z reform w którymkolwiek z ich wzorców tożsamości? Jeśli twierdzenia teoretyków systemowych drugiej fali są prawdziwe, odpowiedzi na powyższe pytania dostarczą wskazówek dotyczących trwałości zmian wywołanych czynnikami zewnętrznymi w kontekście szkolnictwa wyższego w Polsce.

$\mathrm{W}$ celu zbadania interakcji między zewnętrznymi bodźcami zmiany a wzorcami tożsamości w najważniejszych typach polskich instytucji szkolnictwa wyższego, niniejsze badania skupiały się na odkrywaniu „zracjonalizowanych mitów” (Meyer i Rowan 1977; Schriewer 2009) o uniwersytecie wyznawanych przez kluczowych graczy - zarówno twórców polityki naukowej, jak i przywódców akademickich, którzy te reformy wdrażali. Zracjonalizowane mity to przyjęte narracje „przedstawiające różne struktury formalne jako racjonalne środki służące do osiągania pożądanych efektów" (Meyer i Rowan 1977: 345, tlum. własne). W kontekście niniejszych badań pojęcie to, zaczerpnięte z teorii instytucji, służy jako koncepcyjny most umożliwiający operacjonalizację organizacyjnego „DNA” - eksperymentalny klucz do organizacyjnego wzorca tożsamości.

Zracjonalizowane mity nie są „mityczne” w sensie bycia „fałszywymi.” Ich mityczność polega na tym, że ukazują ustaloną konstrukcję świata i wyznaczają zachowania niezbędne do jej podtrzymania. Niniejsze badania opierają się na założeniu, że zracjonalizowane mity tworzą pojedyncze „geny” autopoetycznego „DNA” organizacji. Wykorzystanie tej konkretnej koncepcji jest częściowo uzasadnione neo-instytucjonalnym odkryciem, że zracjonalizowane mity odgrywają szczególnie ważną rolę w organizacjach doświadczających wysokiego poziomu niepewności w otaczającym je środowisku oraz wysokiej potrzeby społecznej legitymizacji - zatem w instytucjach takich jak współczesne uczelnie wyższe. Istnieje hipoteza, że twórcy polityki i liderzy akademiccy w różnego rodzaju instytucjach funkcjonują w różnorodnych systemach społecznych i z tego względu będą komunikować i tworzyć różne struktury, aby osiągnąć pożądane cele. 


\section{Autorytatywny wzorzec reformy zarządzania}

W ostatnich latach „zracjonalizowany mit” występujący powszechnie w sferze europejskiego ustawodawstwa określa instytucje szkolnictwa wyższego jako quasi-rynki sterowane za pomocą mechanizmów konkurencji nadzorowanej przez państwo (Agasisti i Catalano 2006). Mit ten pojawił się w odpowiedzi na postulaty stawiane sektorowi szkolnictwa wyższego, domagające się większej wydajności i wrażliwości na wątpliwości podatników, co miałoby przekładać się na wysiłki rządów europejskich, by dostosować instytucje szkolnictwa wyższego do priorytetów rozwoju społecznego i gospodarczego. Polityki zorientowane na rynek były postrzegane jako formalne struktury i racjonalne narzędzia reform (Bok 2009). Rządy chciały przyznać instytucjom szkolnictwa wyższego większą autonomię w zamian za większą wydajność i sprawozdawczą odpowiedzialność.

Ideologiczne korzenie „zracjonalizowanych mitów” ujętych w nowych szablonach polityk można znaleźć w zasadach nowego zarządzania publicznego, zgodnie z którymi zarządzanie stosujące rozwiązania rynkowe jest uznawane za środek do zwiększenia wydajności sektora publicznego. Trendy w zakresie zorientowania na rynek w zarządzaniu publicznym powstały jako przeciwwaga dla tego, co uczeni nazywają wyłonieniem się nowego „państwa regulacyjnego”, co w Europie oznaczało fundamentalne odejście od państwowo-biurokratycznego „welfaryzmu” (King 2007). Większa autonomia instytucji jest połączona z konkurencyjnymi mechanizmami finansowania i oceny wyników (Gornitzka et al. 2007; Maassen i Olsen 2007; Trakman 2008). Nowe, post-biurokratyczne formy zarządzania podtrzymują zróżnicowane koncepcje misji szkolnictwa wyższego i mają swoje korzenie w różnorodnych tradycjach instytucjonalnych. Niemniej jednak istnieją pewne cechy wspólne, które umożliwiają identyfikację nowego modelu jako „szablonu wspólnej polityki” (Capano i Regini 2014, tłum. własne). Cechy te obejmują:

oddzielenie operacji od tworzenia polityki w ramach jednostek rządowych, formalne rozróżnienie między nabywcami (rząd) a dostawcami (rynek) oraz powołanie niezależnych agencji blisko współpracujących z ministerstwami, aby zachować wpływ na rynek w imieniu społeczeństwa (King 2007: 413).

Niektórzy uczeni stosują termin „nowy menedżeryzm” (Braun i Merrien 1999) jako opis modelu z przedefiniowanymi relacjami między uniwersytetami, rynkami i państwem. Nowy wzorzec można skategoryzować dokładniej jako post-biurokratyczną hybrydę koordynacji rynku i państwa, w którym państwo działa jako arbiter rynku (Gornitzka i Maassen 2000). Autorzy badania trendów w zarządzaniu stwierdzili, że w nowych ramach „to tak, jakby rządy chciały upewnić się, że uniwersytety i inne uczelnie wyższe korzystają z większej autonomii w sposób pozwalający na faktyczne osiągnięcie celów, jakie owa zwiększona autonomia miała przynieść" (Gornitzka i Maassen 2000: 284). 
„Szablon wspólnej polityki” (Capano i Regini 2014: 73) został uznany i wzmocniony przez Unię Europejską w strategii lizbońskiej ogłoszonej w 2000 r., która mocno skupia się na wiedzy jako motorze rozwoju ekonomicznego w Europie. Polityki, takie jak konsolidacja władzy w niewielkim gronie, wzmocnienie powiązań pomiędzy instytucjami szkolnictwa wyższego a środowiskiem społeczno-gospodarczym oraz finansowanie oparte o wyniki stały się autorytatywnym wyznacznikiem reform. Od tamtej pory systemy szkolnictwa wyższego w Europie coraz bardziej upodabniają się do siebie. Jest to zjawisko wnikliwie badane i komentowane przez politologów (teoria konwergencji - zob. np. Heinze i Knill 2008; Dobbins i Knill 2009; Dobbins 2011; Dobbins 2017) oraz socjologów organizacji reprezentujących szkołę neoinstytucjonalną (izomorfizm instytucjonalny - zob. np. Zha 2009 lub systemy światowe - zob. np. Schriewer 2009). Konwergencja w szkolnictwie wyższym to aspekt szerszych procesów globalnego izomorfizmu i normalizacji w edukacji (Schriewer 2009).

\section{Polskie reformy nauki i szkolnictwa wyższego}

Zachodnioeuropejskie przejście w stronę „,szablonu wspólnej polityki” było istotną cechą kontekstu politycznego, w jakim znalazło się szkolnictwo wyższe w Polsce w pierwszej dekadzie XXI wieku. Marek Kwiek, czołowy badacz szkolnictwa wyższego w Polsce, zauważa, że po raz pierwszy od 1989 r.:

„[...] państwo staje się interesariuszem z własnym, odrębnym głosem w sprawie szkolnictwa wyższego. I po raz pierwszy głos państwa jako interesariusza różni się od głosu (części) społeczności akademickiej” (Kwiek 2012: 167).

Przełomowe reformy nauki i szkolnictwa wyższego wprowadzone w latach 20092011 przez ówczesną Minister Nauki i Szkolnictwa Wyższego Barbarę Kudrycką oraz najnowsza Ustawa 2.0: Prawo o szkolnictwie wyższym, omawiane w niniejszym artykule, mają wiele cech wspólnych z europejskim „szablonem wspólnej polityki”. Reformy wprowadzone w latach 2010-2011 zakładały dwa główne cele: 1) wzmożona produkcja nowej wiedzy, operacjonalizowanej z pomocą wskaźników ilościowych w postaci publikacji o wysokim współczynniku Impact Factor; oraz 2) wysoka jakość kształcenia, operacjonalizowana za pomocą Krajowych Ram Kwalifikacji (KRK) zintegrowanego systemu opisu kwalifikacji, który wykorzystuje efekty kształcenia jako główny punkt odniesienia we wszystkich sektorach edukacji. KRK zostały opracowane na podstawie Europejskich Ram Kwalifikacji (ERK) - wynikających z unijnej inicjatywy ujednolicenia kwalifikacji tak, aby były bardziej czytelne i miały swoje odpowiedniki we wszystkich krajach członkowskich. 
W sferze nauki tworzenie polityki naukowej zostało częściowo oddzielone od operacji finansowania nauki dzięki utworzeniu dwóch niezależnych agencji finansujących podstawowe i wdrożeniowe badania: Narodowego Centrum Nauki oraz Narodowego Centrum Badań i Rozwoju. Dotacje na badania statutowe zostały zlikwidowane, a powołane agencje rozdzielają fundusze na zasadach konkurencyjności. W wyniku reformy utworzono również ciało doradcze, czyli Komisję Ewaluacji Jednostek Naukowych, która opracowuje coroczne rankingi na podstawie wyników naukowych. Wsparcie finansowe państwa zależy od otrzymanej oceny - ten mechanizm został utrzymany i wzmocniony w kolejnej fali reform z 2018 roku. Od czasu pierwszej fali reform jednostki akademickie ${ }^{1}$ były oceniane za pomocą zewnętrznie określonych wskaźników i kryteriów obejmujących ilość publikacji pracowników danego wydziału w anglojęzycznych czasopismach naukowych z odpowiednim współczynnikiem Impact Factor (Kulczycki 2017).

W obszarze szkolnictwa wyższego instytucje mają obowiązek stosować Krajowe Ramy Kwalifikacji i przestrzegać standardów oceny, zyskując większą autonomię w zakresie projektowania programów studiów. Na przełomie lat 2010 i 2011 poszerzono kompetencje centralnych organów administracyjnych uczelni o prawo do tworzenia, reorganizacji i zamykania jednostek akademickich. Reforma dała również uniwersytetom dwie opcje, jeśli chodzi o wybór sposobu zarządzania: model tradycyjny lub model określany mianem „menedżerskiego”. W tym drugim modelu rektor miał być wybierany w drodze otwartej rekrutacji i mógł następnie swobodnie prowadzić otwartą rekrutację dziekanów i prorektorów (za wyjątkiem prorektora ds. nauki) i samodzielnie wybierać osoby na te stanowiska. Reforma utrzymała również wymóg wprowadzony w roku 1997 Ustawą o wyższych szkołach zawodowych, dotyczący obowiązku istnienia konwentów w wyższych szkołach zawodowych; w przypadku pozostałych instytucji przepisy zachęcały do lecz nie narzucały obowiązku powoływania takich organów (Poland 2010).

Kompleksowa reforma wprowadzona w 2018 r. za kadencji ministra Jarosława Gowina była kolejnym krokiem w stronę zwiększenia autonomii w zamian za większą rozliczalność według wskaźników rozwoju społecznego i gospodarczego przyjętych przez państwo. Komisja Ewaluacji Jednostek Naukowych została przemianowana na Komisję Ewaluacji Nauki, a jej zadaniem jest obecnie ocena badań w zakresie danej dyscypliny, a nie ocena konkretnych jednostek akademickich uczelni. Nadal opiera się ona na zewnętrznie określonych wskaźnikach skupiających się na uznanych międzynarodowo publikacjach (Poland 2018). Dwie z najważniejszych zmian kierują system mocniej w stronę „,szablonu wspólnej polityki europejskiej”. Nowe prawo poszerza

\footnotetext{
${ }^{1}$ Definicja ta obejmuje podstawowe jednostki organizacyjne uczelni wyższych zgodnie z ich definicjami w statutach, jednostki Polskiej Akademii Nauk, instytuty badawcze, Polską Akademię Umiejętności i inne prawnie zarejestrowane organizacje badawcze.
} 
uprawnienia rektora o wyznaczanie ram organizacyjnych określających strukturę uczelni (co było wcześniej zadaniem organów kolegialnych) oraz wprowadza obowiązek powołania rad uczelni we wszystkich publicznych ISW. Skład owych rad podlegał kontrowersjom - projekt zakładał wstępnie, iż większość członków rady powinna pochodzić spoza danej instytucji, jednak po sprzeciwie ze strony społeczności akademickiej zmieniono ten zapis. Ostatecznie istnieje wymóg, aby zewnętrzni przedstawiciele stanowili co najmniej 50\% rady. Kompetencje rady mają również mniejszy zasięg niż pierwotnie planowano - jej zadaniem jest opiniowanie statutu i strategii instytucji oraz sprawozdań z realizacji strategii, monitorowanie finansów i zarządzania, a także zgłaszanie kandydatów na stanowisko rektora po wcześniejszej ich ocenie przez senat.

Nie było dotąd jasne, w jaki sposób reformy przesuwające system w stronę instrumentalnej wizji uniwersytetu przecinają się ze wzorcami tożsamości różnych rodzajów instytucji, od flagowych uniwersytetów po wyższe szkoły zawodowe. Czy, zgodnie z hipotezą Kwieka (2015: 87), przyczyniają się do konfliktu „fundamentalnych wartości”? Czy naciski, aby ulepszać zewnętrzną adekwatność, były postrzegane jako spójne czy niespójne z wzorcami tożsamości różnych instytucji? Czy w jakimkolwiek wzorcu tożsamości można obserwować oznaki zmian wynikających z reformy? Niniejsze badania, prowadzone pomiędzy pierwszą a drugą falą reform, są próbą odpowiedzi na te pytania.

\section{Metody i realizacja badań}

W badaniu wykorzystano metody jakościowe do zbadania opinii twórców polityki naukowej oraz przywódców akademickich.

Autorka przeprowadziła wywiady w dwóch grupach respondentów: 1) 12 architektów reform z lat 2010-2012 oraz ekspertów zaangażowanych w proces legislacyjny prowadzący do ich uchwalenia; 2) 20 liderów akademickich z czeterch publicznych ISW reprezentujących cztery główne typy instytucji.

A. Flagowa ISW: jedna z dwóch ISW w Polsce znajdująca się w rankingu najlepszych 400 uniwersytetów na świecie, uważana za jeden z dwóch flagowych uniwersytetów w Polsce.

B. Techniczna ISW: jedna z 31 publicznych politechnik w Polsce, z wieloletnią tradycją współpracy z sektorem przemysłowym.

C. Specjalistyczna ISW: jeden z tzw. uniwersytetów przymiotnikowych - uniwersytetów, które powstały ze specjalistycznych instytucji powołanych lub zreorganizowanych po $1946 \mathrm{r}$.

D. Zawodowa ISW: jedna z 36 Państwowych Wyższych Szkół Zawodowych, reprezentująca najmłodszy typ publicznych ISW w Polsce, istniejąca od $1997 \mathrm{r}$.

W każdej ISW przeprowadzono wywiad z rektorem, jednym $\mathrm{z}$ wicerektorów lub byłym rektorem, jedną osobą na wyższym stanowisku kierowniczym, dwoma 
członkami organu zarządzającego i jednym nieformalnym liderem, co ma swoje uzasadnienie w sugestii Sztompki (1993) i innych, że w postkomunistycznym systemie społecznym osoby z największym autorytetem często nie są tymi, które zajmują wpływowe stanowiska. Podsumowanie składu obu prób badawczych przedstawiono poniżej (tabele 1 i 2 ).

Podstawowa metoda wykorzystana w badaniach to wywiad elitarny. W celu zapewnienia wiarygodności danych w kontekście kulturowym, wywiady odbyły się w czasie dłuższego pobytu autorki w kraju. Badaczka miała bezpośredni kontakt ze środowiskiem uczestników badań przez cały rok akademicki (2013-2014) w związku z gościnnym pobytem badawczym w jednostce akademickiej szkolącej liderów i kierowników w sektorze publicznym, również w szkolnictwie wyższym. Osobiste kontakty nawiązane za pośrednictwem pracowników jednostki umożliwiły spotkania z osobami funkcyjnymi i uczestnictwo w wydarzeniach zamkniętych organizowanych przez takie organizacje, jak Fundacja Rektorów Polskich oraz Konferencja Rektorów Akademickich Szkół Polskich. W efekcie badaczka znała respondentów jeszcze przed wywiadami lub posiadała rekomendacje członków nieformalnej sieci kontaktów, co jest rzadkością, jeśli chodzi o badania zwykle prowadzone w tym obszarze. Zauważono, że w społeczeństwach postkomunistycznych ludzie często dzielą silnie sferę publiczną i prywatną, co wiąże się z rozdwojeniem świadomości społecznej (Sztompka 1993: 246). Style komunikowania różnią się znacząco w zależności od tego, czy rozmówca jest postrzegany jako członek sfery publicznej czy prywatnej. Biegłość w języku polskim oraz pozycja badaczki jako bezpiecznej osoby z zewnątrz, a jednak powiązanej z prywatnymi sieciami kontaktów, zwiększają wiarygodność pozyskanych danych w stopniu, jaki rzadko można osiągnąć, prowadząc podobne badania w tym obszarze.

Tabela 1

\begin{tabular}{|c|c|c|c|c|}
\cline { 2 - 5 } \multicolumn{1}{c|}{} & $\begin{array}{c}\text { Ministerstwo Nauki } \\
\text { i Szkolnictwa Wyższego }\end{array}$ & $\begin{array}{c}\text { Architekci } \\
\text { reformy }\end{array}$ & $\begin{array}{c}\text { Eksperci } \\
\text { zewnętrzni }\end{array}$ & $\begin{array}{c}\text { Rzecznicy } \\
\text { polityczni }\end{array}$ \\
\hline Uczestnicy & 3 & 3 & 2 & 4 \\
\hline
\end{tabular}

Objaśnienie: skład próby przedstawicieli rządowych $(\mathrm{n}=12)$.

Tabela 2

\begin{tabular}{|c|c|c|c|c|}
\cline { 2 - 5 } \multicolumn{1}{c|}{} & $\begin{array}{c}\text { Rektor, prorektor } \\
\text { lub były rektor }\end{array}$ & $\begin{array}{c}\text { Osoba na wyższym sta- } \\
\text { nowisku kierowniczym }\end{array}$ & $\begin{array}{c}\text { Członek organu } \\
\text { zarządzającego }\end{array}$ & $\begin{array}{c}\text { Nieformalny } \\
\text { lider }\end{array}$ \\
\hline Flagowa & 2 & 1 & 2 & 1 \\
\hline Techniczna & 1 & 2 & 2 & 1 \\
\hline Specjalistyczna & 1 & 1 & 2 & 1 \\
\hline Zawodowa & 0 & 1 & 1 & 1 \\
\hline
\end{tabular}

Objaśnienie: skład próby przedstawicieli ISW $(\mathrm{n}=20)$. 
Przeprowadzone wywiady zostały poddane transkrypcji i analizie w języku rozmówców w celu zidentyfikowania powtarzających się wątków. Analizę treści przeprowadzono z wykorzystaniem oprogramowania MAXQDA, które posłużyło do porównania wypowiedzi dwóch grup w celu określenia znaczników tożsamości zoperacjonalizowanych jako „zracjonalizowane mity” uniwersytetu. Pierwsza runda kodowania przyjęła klasyczny trójkąt koordynacji Clarka (1986) jako pierwsze źródło kategorii kodowania (Shaw 2018), jednak kody wyłaniające się in vivo z języka samych respondentów zasugerowały strukturę kodowania zbudowaną w oparciu o rozróżnienie między logiką instytucjonalną a instrumentalną. Szczegółowa operacjonalizacja dwóch „zracjonalizowanych mitów” pojawiających się w analizie wywiadów została przedstawiona w załączniku A. Fragmenty wywiadów zostały zakodowane ze względu na odniesienia do danego „zracjonalizowanego mitu” oraz stanowisko mówiącego, aby umożliwić analizę zarówno pozytywnych, jak i krytycznych wypowiedzi.

Zgodnie z przyjętymi ramami teoretycznymi, w badaniu zastosowano podejście interpretatywne oraz przyjęto założenie, że ludzie przypisują otaczającemu ich światu różne znaczenia, które stanowią podstawowy element rzeczywistości społecznej (Menzel 1978; Schwandt 2000). Niezależnie od ich ontologicznej czy epistemologicznej oceny, znaczenia i interpretacje mają realny wpływ na świat tych, którzy je przyjmują. Jak zauważyli Thomas i Znaniecki, jeśli ludzie postrzegają coś jako realne, staje się realne w swoich konsekwencjach. Celem badania była obserwacja i interpretacja rzeczywistości z punktu widzenia respondentów i identyfikacja takich prawidłowości, które byłyby przez nich samych rozpoznane jako prawdziwe (Geertz 1973).

\section{Konflikt zracjonalizowanych mitów - instrumentalna i instytucjonalna wizja uniwersytetu}

Wyniki badań potwierdzają hipotezę Kwieka (2015) o istnieniu konfliktu wartości między decydentami a przywódcami akademickimi, dotyczącego roli uniwersytetów i ich stosunków z państwem. ${ }^{2}$

Twórcy polityki naukowej jednoznacznie zakładają, że „pożądanym efektem” kształcenia na poziomie wyższym jest rozwój gospodarki i społeczeństwa za pomocą „racjonalnych środków” (Meyer i Rowan, 1977: 345) uczciwej konkurencji, stosowanych zgodnie z czysto instrumentalną logiką (rys. B1 w zał. B). Dla przywódców akademickich pożądane efekty i racjonalne środki są mniej jednolite, ale dla większości respondentów w tej grupie uniwersytet to przede wszystkim instytucja, której celem jest bezinteresowne poszukiwanie prawdy w oparciu o wzajemną odpowiedzialność

\footnotetext{
2 Niniejsze badanie nie jest reprezentatywne dla wszystkich polskich instytucji akademickich, dlatego mówiąc o „decydentach/twórcach polityki naukowej” i „przywódcach akademickich” należy pamiętać, że autorka odnosi się do osób uczestniczących w badaniu.
} 
opartą na zaufaniu (rys. B2 w zał. B). Ten wzorzec tożsamości był najsilniejszy w uczelni flagowej i specjalistycznej, a również, choć w nieco mniejszym stopniu, zawodowej. Jedyny typ instytucji, w której nie postrzegano reform jako zakłóceń w realizacji właściwej misji uczelni, to politechnika. Graficzne przedstawienie pozytywnych i negatywnych stwierdzeń respondentów znajduje się w załączniku B.

Co istotne, obie grupy dostrzegają rysy w stosowanych „racjonalnych środkach”, które zagrażają osiągnięciu odpowiednich „pożądanych efektów”. Istnienie tych rys wynika z problematycznego przecinania się dwóch „zracjonalizowanych mitów”. Używając języka teorii systemów, kompensacje mające na celu odtworzenie zdolności systemu do przetrwania zagrażają realizacji pierwotnego wzorca tożsamości, nie przynosząc wyników pożądanych przez źródło nacisków.

Szczegółowe wyniki i dyskusja, koncentrująca się głównie na przedstawicielach uczelni akademickich, zostały zaprezentowane w poniższych dwóch częściach artykułu.

\subsection{Mit instrumentalny - „jeśli państwo za coś płaci, oczekuje konkretnych wyników"}

Twórcy polskiej polityki naukowej wyrażają wyraźnie instrumentalne podejście do sektora szkolnictwa wyższego jako narzędzia polityki państwowej. Ich zdaniem sektor ten powinien wspierać wzrost gospodarczy i społeczny, co będzie możliwe dzięki mechanizmom uczciwej konkurencji. Określenie „konkurencja” zostało użyte 41 razy w 12 wywiadach z twórcami polityki naukowej; dla porównania, termin ten pojawił się 13 razy w 21 wywiadach z przywódcami akademickimi.

W opinii respondentów szkolnictwo wyższe jest zbyt ważne, aby pozostawić je kaprysom mocno niedoskonałego rynku edukacyjnego. Wielu respondentów zauważało, że istnienie naprawdę wolnego rynku jest niemożliwe dopóki „konsumenci” nie są tymi, którzy płacą za „usługi” i decydują o ich wartości - a większość studentów uczelni publicznych w Polsce nie płaci za naukę. Na niedoskonałym rynku państwo, płacąc za publiczną edukację na poziomie wyższym, przyjmuje również rolę przedstawiciela konsumentów:

„[...] jak państwo za coś płaci to wymaga za to konkretnych rezultatów” (108:34).

W tej niedoskonałej sytuacji, w której większość uniwersytetów publicznych jest finansowana bezpośrednio przez państwo, to właśnie państwo musi upewniać się, że środki publiczne są dobrze wydawane i to ono określa, co to znaczy „dobrze”.

Według respondentów z grupy osób tworzących politykę naukową, państwo powinno oceniać skuteczność szkolnictwa wyższego i nagradzać jednostki postrzegane jako strategiczne dla swojego rozwoju. Odzwierciedlając logikę instrumentalną 
i europejski „szablon,” decydenci stwierdzali, że państwo musi ingerować w rynek edukacyjny na korzyść tych, którzy świadczą najlepsze usługi przynoszące największe publiczne korzyści. Żaden z badanych nie wierzył, że „niewidzialna ręka rynku” zapewni najlepszy zwrot z prywatnych lub publicznych inwestycji, przynajmniej nie w bieżącej sytuacji prawnej, ekonomicznej i kulturowej. Obecnie zbyt łatwo jest manipulować potencjalnymi studentami, koszty społeczne są zbyt wysokie, a na wyniki trzeba czekać zbyt długo. Bez jakiejś formy kontroli ze strony państwa zbyt wiele osób będzie chciało zdobyć fikcyjne stopnie naukowe, a zbyt wiele uczelni będzie gotowych takie stopnie nadać. Rynek edukacyjny jest również zbyt niejasny i niedoskonały, aby umożliwić w pełni świadomy wybór, dlatego państwo, które przeznacza tak wiele środków na finansowanie publicznego szkolnictwa wyższego, musi również działać jako arbiter tego, jaki rodzaj kształcenia służy interesom publicznym. Opinia, iż państwo jest sprzymierzeńcem i obrońcą dobra publicznego w sferze szkolnictwa wyższego, została dobrze wyrażona w poniższym stwierdzeniu:

„[...] potencjalnie siły progresywne w szkolnictwie wyższym powinny zauważać takie państwowe zachęty, jeżeli są inteligentne, jako swojego sojusznika” (108:38).

Twórcy polityki wyrażali pogląd, iż to państwo decyduje o rozstawieniu graczy; państwo płaci i wymaga. Respondenci różnili się jednak jeśli chodzi o to, do jakiego stopnia państwo może i powinno stawiać wymagania uczelniom wyższym. Niektórzy twierdzili, że rząd powinien jedynie określić uczciwe zasady, stworzyć przejrzyste systemy informacji, a resztę zostawić rynkowi. Rynek powinien na przykład odgrywać kluczową rolę w ocenie przygotowania absolwentów, nawet tych na poziomie studiów doktoranckich:

„[Podoba mi się] to co jest w Stanach, że młody człowiek kończy studia czy robi doktorat i to świat zewnętrzny go ocenia" (110:40).

Inni respondenci popierali silniejsze zaangażowanie państwa w kontrolę procesu kształcenia, zwłaszcza w zakresie określania wyznaczników jakości i przeciwdziałania patologiom.

Jak w praktyce miałyby wyglądać działania państwa jako rzecznika interesu publicznego? Wobec braku lepszych wzorców, państwo próbowało pełnić tę rolę, określając minimalne poziomy wykształcenia pracowników akademickich prowadzących zajęcia na akredytowanych kierunkach. Prowadzenie studiów licencjackich wymagało od uczelni zatrudnienia co najmniej trzech pracowników naukowych ze stopniem doktora habilitowanego i co najmniej sześciu pracowników ze stopniem doktora w wymaganym obszarze nauki. W praktyce jeden z doktorów habilitowanych mógł być 
zastąpiony dwoma doktorami, a maksymalnie dwa przedmioty mogły być prowadzone przez osoby z tytułem magistra danej dziedziny. ${ }^{3}$ Każdy pracownik naukowy mógł być wliczony tylko raz do minimum kadrowego w danej instytucji. Choć mechanizm ten, jak przyznawano, nie był doskonały, był przytaczany jako przykład ochrony interesów publicznych - co kwestionowali przywódcy akademiccy cytowani niżej.

Pełnoetatowi pracownicy ministerstwa niezwiązani z innymi instytucjami najwyraźniej podkreślali rolę państwa jako organu wyłącznie nadzorczego, ograniczającego swoje działania do finansowania i udzielania akredytacji. Twierdzili, że ich wpływy w systemie szkolnictwa wyższego są o wiele mniejsze niż wpływy samej społeczności akademickiej:

„[...] rola ministerstwa sprawdza się do organu nadzoru tak i tak naprawdę nie nadzoru, kontroli wykonywania tych zadań natomiast pałeczka jest już w $100 \%$ po stronie uczelni” (106:34, pogrubienie własne).

Można jednak zauważyć, że czysto nadzorująca rola ministerstwa była przedstawiana jako aspiracyjny ideał, a niekoniecznie stanowiła obecną rzeczywistość. Twórcy polityki naukowej zdecydowanie uważali, że ich rola powinna być ograniczona, tymczasem realnie jest ona dość znaczna. Podczas kadencji Barbary Kudryckiej (2007-2013), której współpracownicy uczestniczyli w niniejszym badaniu, ingerencja Ministerstwa w zarządzanie szkolnictwem wyższym była bardziej zdecydowana niż w jakimkolwiek innym okresie epoki post-socjalistycznej (Kwiek 2012). Przytaczając zaledwie kilka przykładów, Ministerstwo aktywnie określało kryteria finansowania badań naukowych i przyznawania akredytacji państwowych, wyznaczało strategiczne priorytety finansowania programów uznawanych za kluczowe dla rozwoju kraju i wybierało członków wszystkich najważniejszych organów, takich jak Komisja Ewaluacji Jednostek Naukowych, Polska Komisja Akredytacyjna i Rada Główna Nauki i Szkolnictwa Wyższego. Z tego względu hasła o autonomii ISW mogą być interpretowane albo jako aspiracyjny ideal, albo jako obrona przed postrzeganiem coraz większej ingerencji państwa w szkolnictwo wyższe.

Tak czy inaczej, zdecydowanym celem reform z lat 2010-2011 (przynajmniej teoretycznie) było nadanie ISW wolności w kształtowaniu strategii badawczych i programów studiów, przy zachowaniu przez państwo pośredniej kontroli na poziomie oceny jakości wewnętrznych środków ewaluacji i wyników końcowych:

„Instytucje otrzymały więcej autonomii. Mają więcej wolności, więcej pola do manewru i powstał inny mechanizm - zewnętrzna kontrola jakości, która staje się potrzebna tylko

3 Prawo przewidywało wyjątki od tej zasady dla konkretnych dyscyplin naukowych, które istnieją od dłuższego czasu i mogły zostać potraktowane inaczej. 
w kontekście, gdzie nie ma bezpośredniej kontroli. Jednak dokładnie w tym kontekście ma sens kontrola czy zaangażowanie szerszego społeczeństwa. Dwie strony tej samej monety to autonomia i odpowiedzialność" (107:13).

Tendencja do zwiększania odpowiedzialności i zewnętrznego motywowania do zachowania jakości jest najbardziej widoczna w sposobie oceny i finansowania badan naukowych przez polski rząd. Sposób ten został następująco podsumowany przez członka Komisji Ewaluacji Jednostek Naukowych:

„To nie jest róbta co chceta, tylko róbta co chceta i na koniec roku meldujta z punktami” (102:131).

„Punkty” wspomniane przez respondenta odnoszą się do krajowego systemu ewaluacji jednostek akademickich. Reformy z lat 2010-2011 wprowadzily ranking wydziałów i jednostek w oparciu o wyniki naukowe ich pracowników. Za pomocą kryteriów takich jak współczynnik Impact Factor Komisja Ewaluacji Jednostek Naukowych nadawała każdej jednostce jedną z czterech kategorii, które decydowały o wysokości środków otrzymywanych przez tę jednostkę na badania statutowe przez kolejne cztery lata. Ewaluacja opierała się na rankingu punktów przyznawanych za publikacje naukowe ogłaszanym co roku przez Ministerstwo Nauki i Szkolnictwa Wyższego. 4 Taki mechanizm miał motywować dziekanów i dyrektorów innych jednostek do zatrudniania i zatrzymywania najaktywniejszych pracowników naukowo-dydaktycznych, których osiągnięcia w nauce przekładałyby się na większe fundusze (108). Ponieważ wszystkie inne środki finansowe na badania w Polsce są przyznawane na zasadach konkursów przez niezależne agencje, które również korzystają z rankingu Ministerstwa jako wytycznych ${ }^{5}$, prawie wszystkie środki finansowania badań naukowych mają być rozdzielane zgodnie z zewnętrznie określonymi kryteriami bazującymi na wynikach. Jest to radykalne odejście od dotychczasowych praktyk, gdzie badania statutowe nie były powiązane z wynikami, a o ich przydziale decydowała hierarchia akademicka. W opinii większości twórców polityki naukowej zwrot w kierunku kryteriów opartych na wynikach eliminuje „kumoterstwo” w podziale inwestycji podatników i kieruje system szkolnictwa wyższego i nauki na drogę prowadzącą do większych korzyści dla społeczeństwa.

4 Ranking składał się z trzech części: A) Czasopisma z przypisanym współczynnikiem Impact Factor z listy Thomson Reuters Journal Citation Reports (JCR) (15-50 punktów); B) Czasopisma, które nie mają przypisanego współczynnika Impact Factor (1-10 punktów) oraz C) lista European Reference for the Humanities (10-14 punktów).

5 Badania podstawowe są finansowane przez Narodowe Centrum Nauki (NCN), natomiast badania stosowane przez osobną agencję - Narodowe Centrum Badan i Rozwoju (NCBR). 
Wśród respondentów z tej grupy znalazł się jeden zdecydowany głos podważający zasadność kryteriów opartych na mierzalnych wynikach. Szanowany pracownik naukowy związany z jednym z najlepszych uniwersytetów w kraju, który przez jedną kadencję pracował dla Ministerstwa Nauki i Szkolnictwa Wyższego, postrzegał logikę wyznaczania celów i wymagania efektów jako szkodliwą dla prawdziwej kreatywności i faktycznego rozwoju:

„[...] autonomia uczelni jest gwarantem akademickiej swobody myśli, kreatywności, twórczości, że jak się zada i jak się będzie tylko pewne rzeczy finansować i z pewnych rzeczy rozliczać, to po prostu się hamuje rozwój tak naprawdę" (103:52).

Zgodnie z tą opinią uniwersytet to kuźnia nowych pomysłów kluczowych w procesie tworzenia innowacji, a wiele takich pomysłów nie pojawi się, jeśli wszystko będzie mierzone i rozliczane. Instrumentalna i instytucjonalna rola szkolnictwa wyższego są równoważne, a ostatnie reformy posunęły się za daleko w próbach zmierzenia tego, co niemierzalne.

Twórcy polityki mówili o trzech sposobach stosowanych przez państwo, by zachęcać instytucje szkolnictwa wyższego do osiągania pożądanych wyników:

I. Obowiązek uwzględnienia ocen pracowników naukowo-dydaktycznych przez studentów.

II. Obowiązek gromadzenia danych o losach absolwentów, a od 2015 r. publikowanie danych przekrojowych dotyczących zarobków absolwentów na podstawie krajowej bazy danych szkolnictwa wyższego oraz anonimowych danych administracyjnych ZUS (Polish Graduate Tracking System 2018).

III. Wdrożenie Polskich Ram Kwalifikacji (PRK), opracowanych w oparciu o Europejskie Ramy Kwalifikacji, składających się z ośmiu poziomów kwalifikacji i trzech kategorii efektów kształcenia: wiedzy, umiejętności i umiejętności społecznych.

Od wprowadzenia reform w latach 2010-2011 uczelnie wyższe muszą opracowywać programy studiów, uwzględniając efekty kształcenia opisane w PRK, aby otrzymać odpowiednie akredytacje (Educational Research Institute 2013). W przeszłości Ministerstwo prowadziło stałą listę 118 kierunków studiów z opisem wymaganych komponentów. Obecnie ISW mają większą autonomię w projektowaniu programów nauczania, pod warunkiem zachowania zgodności z PRK. W procesie akredytacji Polska Komisja Akredytacyjna sprawdza, czy uzyskiwane efekty kształcenia są zgodne z celami sformułowanymi w programach nauczania. W dalszej części artykułu wyraźnie widać, że wszystkie trzy mechanizmy są postrzegane przez przywódców akademickich jako dość problematyczne, a owa niechęć jest zakorzeniona w fundamentalnej niezgodzie co do misji uczelni wyższych. 
Podsumowując, instrumentalne podejście państwa do szkolnictwa wyższego widoczne w wypowiedziach respondentów i bieżącej polityce wskazuje na strategiczną rolę motywowania do osiągania wyników - czy to poprzez zwiększenie konkurencyjności w obszarze badań naukowych, upewnianie się, że ISW dokonują oceny stopnia realizacji założonych celów, czy poprzez upublicznianie wiarygodnych informacji o wynikach. Wady tego podejścia są widoczne dla osób zaangażowanych w administrowanie tradycyjnymi, flagowymi uniwersytetami. Problematyczność „zracjonalizowanego mitu" jest ukazana poprzez przywołanie uwarunkowań niedoskonałego rynku edukacyjnego oraz dążeń państwa do narzucania i regulowania w większym zakresie niż to potrzebne z punktu widzenia respondentów.

\subsection{Mit instytucjonalny - "chroniony przed racjonalnością rynku”}

Dla większości badanych przywódców akademickich szkolnictwo wyższe nie jest przede wszystkim instrumentem rozwoju, lecz instytucją zajmującą się bezinteresownym poszukiwaniem prawdy i tworzeniem szeroko wykształconych obywateli. W kontekście gospodarki opartej na wiedzy korzyści, jakie uczelnie wyższe dostarczają jednostkom i gospodarkom, są uznawane przez respondentów za niezwykle istotne i są traktowane bardzo poważnie, mimo iż są one zaledwie efektami ubocznymi ważniejszej misji. Profesor, który przez wiele lat szkolił władze różnych uczelni, powiedział:

„Uniwersytet ma dwa obowiązki - z jednej strony podtrzymywać tradycję, czyli to, co jest czynnikiem tożsamościowym danej społeczności, a z drugiej strony ma obowiązek przeciwstawiać się czemuś, co jest dla tej społeczności szkodliwe... To jest misja uniwersytetu, że prawdę trzeba głosić i przeciwstawiać się błędowi. I to jest najlepsze określenie misji uniwersytetu" (206:28, pogrubienie własne).

Inny z respondentów stwierdził:

„Istotą uniwersytetu jest bezinteresowność. Jeśli uniwersytet jest podporządkowany: a) polityce, b) biznesowi - to wtedy jest ciałem, które spełnia zamawiane usługi” (217:43; pogrubienie własne).

Celem szkolnictwa wyższego jest przesuwanie granic wiedzy i zapewnianie studentom dostępu do całościowej edukacji, gdzie umiejętności związane z zatrudnieniem nie są na pierwszym miejscu. Takie uczucia były najsilniej wyrażane przez przedstawicieli uczelni flagowej.

Idea poszukiwania i przekazywania prawdy była postrzegana jako zagrożona przez ostatnie zmiany polityczne, których celem jest uczynienie z instytucji szkolnictwa 
wyższego motorów wzrostu gospodarczego. Wyraźnym wyjątkiem była politechnika, której przedstawiciele narzekali bardziej na wynikającą z reform większą biurokrację związaną z dokumentowaniem wyników - takie zastrzeżenia mieli również twórcy polityki. Jednocześnie dążenie do połączenia szkolnictwa wyższego i nauki oraz rynku było postrzegane jako pozytywne. Co ciekawe, opinii tej nie wyrażali przedstawiciele wyższej szkoły zawodowej, której celem jest praktyczne kształcenie zawodowe. Jedynie pracownicy politechniki uważali, że poszukiwanie prawdy i osiąganie zysków finansowych przez uczelnie wyższe to cele, które się uzupełniają.

Przedstawiciele wszystkich typów instytucji wyrażali się mniej pochlebnie o programach kształcenia zawodowego, które mają przygotowywać absolwentów do wykonywania konkretnych zawodów. Najgorętsza dyskusja dotyczyła misji ISW opartej na szeroko rozpowszechnionym poczuciu, iż celem ISW jest zapewnienie obszernej wiedzy, a nie wąskich umiejętności zawodowych. Przywódcy flagowego i specjalistycznego uniwersytetu szczególnie stanowczo sprzeciwiali się idei, jakoby zadaniem uniwersytetu było zapewnienie jedynie wyspecjalizowanych szkoleń dla pracowników:

„[...] jeżeli [pracodawca] traktuje to, że nie mamy programu studiów, który mu dokładnie przygotowuje człowieka na to stanowisko, to my tak nie mamy. Uczelnie nie po to są" (201:38, pogrubienie własne).

Podobne argumenty są często przytaczane w polskich mediach, np. w słynnym już wykładzie inauguracyjnym nowego rektora Uniwersytetu Warszawskiego wygłoszonym w październiku 2013 r. Najmłodszy rektor w najnowszej historii powiedział:

„Uniwersytet to nie firma, a księgowość nie jest królową nauk. Uniwersytet to instytucja, w której tworzą się nowe idee. Dlaczego tylko praktyczne, wąsko pojmowane kwalifikacje wciąż mają być jedynym znakiem rozpoznawczym Polski? Czy tylko tyle mamy do zaoferowania Europie i światu? Czy spawacze rozwiążą problemy społeczne i gospodarcze Polski i Europy, a nasze szwaczki przebiją te z Bangladeszu?" (Gazeta Wyborcza, 01.10.2013, pogrubienie własne).

Obraz uniwersytetu jako świątyni wiedzy był najsilniej postulowany przez pracowników flagowej i specjalistycznej ISW, których poglądom towarzyszyła niezwykle negatywna ocena umasowienia systemu szkolnictwa wyższego. Jednak nie tylko tam, lecz we wszystkich czterech typach instytucji przywódcy akademiccy chcieli powrotu do czasów, kiedy było mniej studentów, mniejsze grupy seminaryjne i więcej możliwości budowania relacji mistrz-uczeń. Przyznawali, że nie wszystkie ISW muszą być uniwersytetami $\mathrm{w}$ tradycyjnym rozumieniu, jednak żaden $\mathrm{z}$ nich nie chce być czymkolwiek innym. W ślad za rektorem Uniwersytetu Warszawskiego twierdzili, 
że różne szkoły zawodowe są potrzebne dopóki ktoś inny, nie ich instytucja, będzie spełniać tę rolę.

Większość przywódców akademickich, za wyjątkiem pracowników politechniki, opisywała rzeczywistość umasowienia i nakazu dostosowania kształcenia do wymogów praktycznych w sposób sugerujący, że są to niepożądane zakłócenia sprzeczne z właściwą misją ISW. Co ciekawe, takie opinie przeważały również wśród przedstawicieli szkół specjalistycznych i zawodowych, a więc instytucji, których oficjalna misja odnosi się do rozwoju praktycznych kompetencji. Przedstawiciele obu tych instytucji twierdzili, że gdyby mogli, usunęliby określenie „zawodowa” lub przymiotnik w nazwie uczelni i przyjęli taki sam status, jak „normalne”, tradycyjne uniwersytety. Respondenci z uniwersytetu flagowego narzekali na dewaluację terminu „uniwersytet”. Co ciekawe taką samą krytykę wyrazili pracownicy uniwersytetu specjalistycznego, który sam przybrał nazwę „uniwersytet” w ciągu ostatnich dwudziestu lat.

Opór wzorca organizacyjnego utworzonego wokół misji zdobywania wiedzy i zapewniania liberalnego kształcenia wydaje się być podtrzymywany przez dwa główne procesy. Po pierwsze większość ISW powstała w oparciu o organizacyjny wzorzec tradycyjnych uniwersytetów, z których pochodzą również pracownicy naukowi:

„Jak Pani spojrzy na kadrę tych uczelni właśnie, nazwijmy to typu państwowe szkoły zawodowe, nie mówiąc o uczelniach niepublicznych, to jest kadra, która przeszła z dużych uniwersytetów publicznych. Mały procent jest ludzi wychowanych na tych uczelniach. To jest bardzo prosto wyjaśnić, ponieważ te uczelnie nie mają najczęściej uprawnień albo mają co najwyżej uprawnienia do nadawania stopnia doktora w niektórych tylko dyscyplinach, no więc kadra pochodzi i jest wychowana na takich wzorcach" (213:46).

Tożsamość uczelni wyższej jako samorządnej społeczności poszukującej prawdy nie jest jedynie kwestią kultury. Reformy systemu szkolnictwa wyższego wprowadzane do 1990 r. były opracowywane przez ekspertów wywodzących się z tradycyjnych uniwersytetów, którzy tworzyli przepisy i zasady finansowania, które jednakowo odnosiły się do uniwersytetów flagowych i uczelni zawodowych. Nawet reforma z $2011 \mathrm{r}$. umożliwiła otwieranie nowych kierunków studiów niewymagających zatwierdzenia przez ministerstwo jedynie instytucjom i jednostkom, które mają uprawnienia do nadawania habilitacji. Zasady finansowania również faworyzują ISW o profilach akademickich:

„Przyznawanie stopni i tytułów to moc - daje większą autonomię, większe dotacje. Prestiż jest większy, bo możemy kształcić własną kadrę i kadrę dla innych. Ma znaczenie w rankingach $i$ algorytmach finansowania" (218:56). 
Krytykując wysiłki rządu, przywódcy akademiccy dostrzegają jednak i akceptują fakt, że aby realizować swoje cele, ISW muszą w dzisiejszych czasach grać zgodnie z regułami rynku. Rynek jest źródłem zasobów, więc należy się z nim liczyć - jednak wszędzie, poza politechniką, ta rzeczywistość jest postrzegana jako taka, z którą trzeba żyć, którą należy nawet maksymalnie wykorzystać, ale nie można pozwolić by naruszyła misję uniwersytetu.

W efekcie działania sił rynkowych badania stosowane, traktowane dotąd z lekką pogardą, zyskały obecnie wyższy status ze względu na pieniądze, jakie przynoszą, zwłaszcza wśród przedstawicieli politechniki:

„Żadne stosowane tam rzeczy, jeszcze niedawno było tu uważane za gorszy rodzaj nauki. Już tak nie jest. I to się już teraz zmienia" (207:31).

Jednak nawet na tej uczelni, która ma najsilniejsze powiązania z przemysłem, niektórzy respondenci nie patrzyli przychylnie na zwiększoną wartość przyznawaną badaniom stosowanym:

„Najbardziej cenione jest ściąganie grantów, wielkich grantów przemysłowych, które na pewno mogą mieć jakiś pożytek dla kraju. Ale żeby one miały pożytek dla rozwijania wiedzy? Nie mam takiego zdania na ten temat" (214:9).

Nawet w tej instytucji granty na badania podstawowe przyznawane przez Narodowe Centrum Nauki były postrzegane jako bardziej prestiżowe niż granty na badania stosowane przyznawane przez Narodowe Centrum Badań i Rozwoju.

To, co łączyło przywódców wszystkich instytucji wszystkich typów, to pogląd, że dążenia ministerstwa do skierowania ISW w stronę większego zaangażowania w sferę społeczną i gospodarczą za pomocą zobowiązań i pomiarów wyników przynoszą efekty przeciwne do zamierzonych - te „racjonalne” środki nie generują wyników pożądanych przez ministerstwo. Dziekan uniwersytetu flagowego tak podsumował krytykę obecnego stanowiska rządu:

„Gospodarka powinna być innowacyjna, ale nie wiem, czy można odgórnie nakazać innowacyjność dekretem dziekana, rektora czy ministra” (224:19, pogrubienie własne).

Ta opinia była wyrażana w różnym stopniu przez pracowników wszystkich typów uczelni, którzy twierdzili, że, koncentrując się na wydajności, rząd pozbawił ISW swobody, jakiej potrzebują, aby tworzyć prawdziwe innowacje (podobne wątpliwości wyrażali również twórcy polityki). Pracownicy naukowi mogą prowadzić dowolne 
badania pod warunkiem, że pozyskają fundusze od instytucji, które rozdzielają je zgodnie z kryteriami uznawanymi za strategiczne dla państwa. Mogą uczyć, czego chcą, dopóki jest to zgodne z KRK. Podczas gdy obowiązujące przepisy mogą odzwierciedlać ideologiczny zwrot w stronę większej autonomii i odpowiedzialności, to jednak cały zestaw regulacji uniemożliwia zastosowanie tej autonomii w praktyce.

Czworo respondentów opisało obowiązujące prawo za pomocą tego samego słowa: "gorset” (210, 213, 214, 217). Poczucie skrępowania było szczególnie powszechne wśród dziekanów, jako tych, którzy piastują stanowiska średniego szczebla w strukturach ISW:

„Jestem w gorsecie zapisów. Ja nie mogę nic zrobić” (217:51).

Kierownicy jednostek akademickich, z wyjątkiem politechniki, powiedzieli, że są ograniczani przez przepisy i nadmiernie obciążeni biurokracją, aby zarządzać w strategiczny i kompetentny sposób. Respondenci podawali wymowne przykłady na to, jak ich możliwości tworzenia atrakcyjnych kierunków studiów zgodnych z KRK są ograniczane ustalonymi przez państwo wymogami prawnymi dotyczącymi ochrony jakości kształcenia.

Na przykład, w zawodowej ISW, ograniczenia prawne uniemożliwiły uruchomienie kierunków finansowanych ze środków publicznych w zakresie informatyki, inżynierii materiałowej i agroturystyki - obszarów, które dotyczą rozwijających się sektorów gospodarki. Wniosek o uruchomienie studiów informatycznych został odrzucony, ponieważ zbyt wielu doktorów wymienionych w minimum kadrowym uzyskało swoje stopnie w dyscyplinach innych niż informatyka. Przedstawiciel wyższej kadry zarządzającej wyjaśnił, że bardzo trudno jest znaleźć potencjalnych wykładowców ze stopniem doktora informatyki - jest tak z uwagi na to, że zapotrzebowanie na takich specjalistów przewyższa podaż, tymczasem mogą oni zarobić poza uczelnią trzy do czterech razy więcej. Istnienie tego samego problemu potwierdził dziekan wydziału politechniki, który powiedział, że zdarzyło mu się już szukać jednocześnie kandydatów na siedem stanowisk, na które nie miał chętnych (216). W przypadku zawodowej ISW, gdyby nie zbyt restrykcyjne przepisy, uczelnia mogłaby zatrudnić osoby z tytułem magistra, na przykład w roli starszych wykładowców - tacy pracownicy byliby dla uczelni bardziej przydatni. Niektórzy respondenci zauważyli, że osoby z wyższymi stopniami naukowymi kształcące się w publicznych uniwersytetach o profilu badawczym przenoszą swoje preferencje stawiania teorii ponad praktykę na zajęcia w zawodowych ISW - a te istnieją, by kształcić studentów w praktycznych dziedzinach (213:46). Z powodu wymogów minimum kadrowego administrator zawodowej ISW szukał doktorów innych dyscyplin naukowych, które wykorzystują informatykę, np. fizyki kwantowej, a mimo to wniosek i tak został odrzucony (220). 
Odrzucono również wnioski zawodowej ISW o utworzenie kierunków studiów z zakresu inżynierii materiałowej i agroturystyki. Powodem był brak odpowiednich laboratoriów i infrastruktury na uczelni, mimo iż ta podpisała porozumienia z firmami i uczelnią partnerską, które zgodziły się udostępnić swoje zaplecze, dopóki ISW nie rozwinie własnego. Wniosek został odrzucony ze względu na przepis wymagający od ISW udowodnienia, że posiada niezbędne pomieszczenia na terenie uczelni. W czasie prowadzonych badań, zawodowa ISW oferowała studia na takich kierunkach, jak politologia, filologia, zarządzanie i pedagogika. Podsumowując, jeden z administratorów powiedział wprost: „mamy świadomość tego, że wypuszczamy absolwentów, których nikt nie zatrudni” (221:32). Kierownictwo tej uczelni zdaje sobie sprawę z tego, że ich oferta dla studentów nie jest spójna z treścią ich misji ani z oczekiwaniami studentów, jednak nie mają mocy sprawczej, aby to zmienić.

Przedstawiciele rządu wyjaśniali, że rosnące regulacje mają trzy zadania: 1) wyeliminowanie patologii; 2) spełnienie obowiązku harmonizacji systemów wewnątrz Unii Europejskiej oraz 3) promowanie wysokiej jakości nauczania i badań. Urzędnik, który wymienił te trzy cele, przyznał również, że, za wyjątkiem nowych mechanizmów przyznawania grantów, nowe instrumenty to przede wszystkim nakazy i zakazy:

„Powiedziałbym takie represyjne trochę podejście, że na przykład za dużo tych wieloetatowości, to zabronimy wieloetatowości. Jest za dużo nepotyzmu, to zabronimy nepotyzmu" (108:6).

Według przywódców akademickich efekt jest taki, iż zastosowane metody eliminacji patologii tworzą kolejne patologie $(217,222)$. Na przykład odkąd prawo zakazało pracy na dwóch pełnych etatach, w sytuacji, gdy wynagrodzenie pracowników akademickich wciąż plasowało się poniżej średniej krajowej, byli oni zatrudniani na podstawie umów „śmieciowych” za jeszcze niższe wynagrodzenia, co skłaniało do pracy w jeszcze większej liczbie instytucji. Coraz większe ograniczenia w obszarze finansów publicznych, z których wiele doczekało się niespójnych interpretacji ze strony urzędników, zniechęcają przywódców akademickich do starania się o środki publiczne ze względu na strach przed audytem i karami grożącymi za niezachowanie zgodności z przepisami. „Gorset” prawny, który miał w zamierzeniu chronić jakość, odebrał elastyczność działania zarówno urzędnikom, jak i pracownikom naukowo-dydaktycznym, zniechęcając ich do przedsiębiorczości. Nawet ci, którzy popierają idee stojące za wprowadzonymi regulacjami, uważali, że ich pierwotny cel został zniwelowany lękiem:

„To jest jak to w Polsce, to znaczy system dobry, a ze strachu urzędnicy żądają więcej niż trzeba. To samo dotyczy także wniosków do Unii Europejskiej, gdzie tam są kryteria lagodniejsze, u nas się je zaostrza ze strachu" (219:21). 
W opinii przywódców akademickich ISW nie są już niezależnymi społecznościami uczonych, a nawet jeśli są, to pozostają takimi dzięki balansowaniu na granicy prawa. Jednocześnie ISW są także instrumentami narodowego rozwoju, do którego dąży rząd. Są czymś pomiędzy, a ich niejasna pozycja nie sprzyja realizacji żadnej z tych dwóch wizji.

Dziekani w szczególności zauważali, że nawet jeśli rząd twierdzi, że chce oceniać wyniki, to w rzeczywistości nie ufa uniwersytetom i dlatego kontroluje najdrobniejsze elementy procesów kształcenia i badawczych, pozostawiając niewiele przestrzeni dla strategicznego przywództwa realizowanego z poziomu poszczególnych ISW. Warto zwłaszcza przytoczyć stwierdzenie dziekana politechniki, który surowo ocenia nowy system. Jego wypowiedź jest tym bardziej uderzająca, iż pochodzi z ust osoby, która popierała cele reformatorów silniej niż większość respondentów:

„To tak samo jak za komunizmu, w konstytucji było napisane, że wszyscy są wolni, jest wolność zgromadzeń, wolność słowa, tylko tyle, że musi być regulowana. U nas też jest pełna autonomia, tylko tyle, że musi być regulowana. Ilość zarządzeń, które bez przerwy są przez ministerstwo wysyłane do uczelni, jest taka, jakiej nie było absolutnie za poprzedniego reżimu" (214:61-62, pogrubienie własne).

Skoro przywódcy akademiccy widzą wolność jako konieczny warunek właściwego funkcjonowania szkolnictwa wyższego i tak ostro krytykują rząd za wysiłki zmierzające do regulacji, to jakie jest ich postrzeganie odpowiedniej formy oceny i odpowiedzialności? Wbrew opiniom urzędników państwowych, tego, co kluczowe dla misji uniwersytetu, nie da się zmierzyć:

„[...] z uniwersytetu nie da się zrobić firmy dlatego, że uniwersytet, oprócz oczywiście tych komercyjnych różnych, ma jeszcze jedno zadanie - kształcić ludzi w sposób niemierzalny" (219:59, pogrubienie własne).

Mechanizmy oceny i odpowiedzialności, o których przywódcy akademiccy wypowiadali się przychylnie, są nieformalne i niepisane, pozwalające na elastyczność i umożliwiające swobodne dążenie do wiedzy wraz ze studentami. Pojęcie wymiernej miary jakości w kształceniu studentów postrzegane było jako szczególnie utopijne. Ze spostrzeżeniem tym zgadzają się nawet decydenci. Chociaż niektórzy z nich mogli marzyć o uwzględnianiu wskaźników zatrudnienia absolwentów w algorytmie finansowania $(104,108,110,111)$, nikt nie uznał tego za wykonalne - ponieważ przesłaniałoby to edukacyjną wartość dodaną i karało ISW zorientowane na słabo przygotowanych studentów. Ponieważ jakości nauczania nie da się zredukować 
do ilościowych wskaźników tak łatwo, jak jakości badań, jest ona kontrolowana i regulowana na papierze - ale w rzeczywistości nie jest ceniona.

Dla przywódców akademickich objętych niniejszym badaniem idealny mechanizm oceny i odpowiedzialności jest kwestią kultury organizacyjnej, a nie arkusza excelowskiego ze znormalizowanymi punktami. Jedynym mechanizmem odpowiedzialności, który nie tłumi kreatywności, jest taki, w którym badacze oceniają siebie nawzajem na zindywidualizowanych zasadach. Ten rodzaj oceny nadal funkcjonuje - pomimo wysiłków rządu zmierzających do jego obiektywizacji i normalizacji:

„Musi być jakiś system weryfikacji i on w gruncie rzeczy jest w środowisku, bo w każdym środowisku, moim na przykład, to jest znana hierarchia, kto jest dobry, a kto jest gorszy. Ona jest niepisana i te punkty nic nie zmieniają" (219:33).

Ocena twórczych przedsięwzięć akademickich, zarówno w dziedzinie nauczania, jak i badań naukowych, jest zbyt złożona, aby zredukować ją do zestawu zewnętrznie określonych wskaźników. Przykładem przywoływanym w kilku kontekstach był przypadek Immanuela Kanta - jednej z najbardziej znaczących postaci zachodniej filozofii. Zgodnie z obecnymi kryteriami zasadzającymi się na punktach, zostałby on zwolniony, ponieważ przez wiele lat napisał tylko jedną, niezbyt obszerną książkę. Dobry system oceny akademickiej wspiera osoby takie jak Kant, zamiast eliminować je w imię spełniania norm wydajności.

Pomimo oczywistej zgody co do tego, że ideałem jest wzajemna odpowiedzialność naukowców połączona z zaufaniem społecznym, pewna mniejszość respondentów zakwestionowała możliwość realizowania tego ideału w Polsce ze względu na deficyt zaufania (203, 205, 214, 217, 222). Głosy te nie są zaskakujące, jeśli weźmie się pod uwagę kluczową rolę zaufania $\mathrm{w}$ wyidealizowanym systemie $\mathrm{w}$ kraju $\mathrm{z}$ jednym z najniższych poziomów zaufania społecznego w Europie (European Social Survey 2018). Dylemat ten został trafnie ujęty przez osobę, która powiedziała:

„Żeby nauka mogła normalnie funkcjonować, potrzeba zaufania. Zaufania w polskiej nauce brakuje" (222:16).

Podczas pięciu rozszerzonych wywiadów przychylnym wypowiedziom na temat ideału wzajemnej odpowiedzialności towarzyszyły zdania takie jak: „oczywiście to jest utopia” (217), „to rodzaj kultury akademickiej, jakiej nie będziemy tu nigdy mieć” (214) lub „to praktycznie niemożliwe” (203). Kilka innych osób opisało swoje nadzieje związane z tym, czym mogłyby być uniwersytety, a następnie wyjaśniło, dlaczego to nie zadziała. $W$ oczach tych pięciu respondentów kulturę polskiego środowiska akademickiego cechuje to, że osobiste i instytucjonalne cele są często realizowane 
dzięki unikaniu formalnych zasad i oficjalnie określonych procesów. Narzekając na rosnącą regulację i wyrażając nostalgię za oceną opartą na zaufaniu, niektórzy respondenci wypowiadali się następująco:

„To w Polsce w ogóle nie działa. Takie jest moje wrażenie. Ale to nie wina rządu, winna jest kultura" (214:11).

Przez dwadzieścia lat po transformacji ustrojowej środowisko akademickie rządziło się demokratycznymi zasadami, ciesząc się swobodą ustalania własnych priorytetów i samoregulacją. Ze względu na mentalne i społeczne nawyki podkopujące zaufanie, wprowadzenie oceny opartej na zaufaniu doprowadziły do systemu nagród, który w rzeczywistości sprzyjałby tym, którzy radzili sobie gorzej. Biorąc pod uwagę nadużycia oceny opartej na zaufaniu, niektórzy respondenci byli zdania, że trudno się dziwić temu, że ministerstwo przyjęło bardziej zdecydowane stanowisko. Chociaż nie zgadzają się z wprowadzonymi rozwiązaniami, dobrze rozumieją ich powody:

„Środowisko akademickie pokazało przez 20 lat, że nie potrafi samo sobą zarządzać, nie potrafi samo wyznaczyć sobie priorytetów. Chociaż nie zgadzam się z ministerstwem, to ich rozumiem. Skoro nie umiecie się sami rządzić, to będziecie mieć hegemona" (222:11, pogrubienie własne).

Elementy kultury podawane jako sprzeczne z podstawowymi wymaganiami wstępnymi oceny i odpowiedzialności opartej na zaufaniu opisywano następująco:

„[...] u nas jest to też pochodna w jakimś sensie takiej mentalności: Polak załatwi, Polak zakombinuje, może tutaj jest bardzo ostry sąd, może nawet za ostry... Polacy doskonale umieją obchodzić różne zapisy na różne sposoby i funkcjonują ludzie wpływowi o dawnej mentalności i młode pokolenie jest podobne (219:25,57, podkreślenie dodane)

Respondent użył tu terminu „kombinować”, oznaczającego „ogranie systemu”, czyli takie zmanipulowanie sytuacji, żeby osiągnąć swój cel. Choć angielskie thumaczenie tego terminu (finagling) ma wydźwięk pejoratywny, polskie słowo jest go pozbawione - sugeruje odnalezienie drogi przez wiele przeszkód. Ilustruje to poniższy cytat:

„Tutaj to kombinowanie takie, ja nie mówię tego w złym słowie, tylko takie szukanie obejść wszystkiego" (210:8). 
Zdaniem tych respondentów „kombinowanie” jest nawykiem, który kwitł w czasie komunizmu, odszedł na dalszy plan w ciągu dwóch dekad samorządności, po czym został niestety ponownie wzmocniony przez nierealistycznie przerośnięte prawo, którego nie da się przestrzegać bez napotykania sprzeczności. Przywódcy akademiccy uznali, że normalne funkcjonowanie ich ISW jest możliwe tylko dzięki lukom i sprzecznościom w przepisach. Uwięziło to ludzi w potrzasku pomiędzy wyborami, z którymi etycznie się nie zgadzają - tak jak w przypadku, kiedy prawo wymaga od nich przeprowadzenia otwartego konkursu na stanowisko, które ma nadzieję otrzymać ceniony doktorant, który nie ma szans na zatrudnienie w innym miejscu ze względu na fakt, że w prawie wszystkich przypadkach zatrudnianie na stanowiskach akademickich odbywa się w ramach danej instytucji.

Respondenci podali wiele przykładów wymijających zachowań, które pozwoliły im osiągnąć cele pomimo przepisów postrzeganych jako restrykcyjne, nierealistyczne lub niesprawiedliwe. Na przykład osoba z technicznej ISW, która doprowadziła do imponującego awansu tej uczelni w rankingach oraz do istotnej poprawy jej sytuacji finansowej powiedziała, że była w stanie tak poprowadzić uczelnię jedynie dzięki „kreatywnemu” zarządzaniu finansami, co wymagało wprowadzenia dostosowań, których legalność była wątpliwa. Dziekan specjalistycznej ISW opisywał, w jaki sposób możliwe było obchodzenie niesprawiedliwych mechanizmów wynagradzania międzynarodowych publikacji w języku angielskim na polu filologii polskiej. Zawarto nieformalne porozumienie o wzajemnej publikacji ze znajomą jednostką w Czechach i wydawano tuż za granicą to samo, co można by było opublikować bez przeszkód we własnym czasopiśmie, gdyby nie obowiązywał ten przepis. Tego rodzaju przykłady były swobodnie i otwarcie przytaczane w mniej więcej połowie wszystkich wywiadów z przywódcami akademickimi.

Powstaje jednak problem z „kombinowaniem”, nawet jeśli może ono być rozsądną reakcją kompensacyjną na inwazję instrumentalnego „zracjonalizowanego mitu” wprowadzanego nadmiernie zbiurokratyzowanymi metodami. „Kombinowanie” pogłębia erozję zaufania - zarówno pomiędzy naukowcami, jak i w ich stosunkach ze społeczeństwem. Tymczasem zaufanie jest podstawą zracjonalizowanego mitu wyznawanego przez przywódców akademickich. Brak zaufania przekłada się na więcej prób kontroli, co powoduje więcej uników - i koło się zamyka.

Podsumowując, logika wyznawana przez większość przywódców akademickich bazuje na zaufaniu społecznym do naukowców, od których oczekuje się podtrzymywania norm moralnych w dążeniu do służby prawdzie oraz wzajemnej odpowiedzialności, przy jednoczesnej ochronie przed kaprysami rynku - to „zracjonalizowany mit" sproblematyzowany przez realia niskiego zaufania społecznego i szeroko rozpowszechnione mechanizmy unikania regulacji postrzeganych jako ograniczające. 


\section{Dyskusja}

Wyniki niniejszego badania ukazują się wraz z wprowadzeniem kolejnej fali reform znanych jako Ustawa 2.0. Pomimo tego, iż wprowadziła je odmienna partia polityczna, stoi za nimi ten sam instrumentalny mit. Niniejsze badania nie tylko uwiarygodniają hipotezę Kwieka (2015) o konflikcie podstawowych wartości pomiędzy środowiskiem akademickim a decydentami politycznymi. Zasadniczo, patrząc przez pryzmat teorii systemów drugiej fali, ukazuje się z nich także obraz systemu angażującego się w „kompensacje” wobec zewnętrznej „perturbacji,” co naraża na szwank zarówno rezultaty zamierzone przez źródło perturbacji, jak i własny wzorzec samoodtwarzania systemu. Wobec zewnętrznej presji na osiąganie „pożądanych celów” określanych przez państwo, reakcją społeczności zakorzenionej w innej tożsamości i lojalnej wobec innego ,zracjonalizowanego mitu” jest pozostanie w pozornej zgodzie z nowymi wymaganiami, przy jednoczesnym zachowaniu zasadniczych nawyków charakterystycznych dla uniwersytetu jako niezależnej i nieuwikłanej instytucji.

Nadmierne poleganie rządu na biurokratycznych metodach, do którego zresztą przedstawiciele tego systemu sami się przyznają, wydaje się być wynikiem trafnego rozpoznania odmiennego wzorca tożsamości, wdrażającego inną agendę niż ta promowana przez rząd, co wyklucza zaufanie, że realizowane są wspólne cele. Pracownicy naukowi nie mieli innego wyboru niż dostosowanie się do zmieniających się regulacji i systemu nagród, ale rodzaje tych adaptacji powinny skłonić środowisko decydentów do zastanowienia. Kiedy prawo nakazuje przeprowadzanie otwartych konkursów na stanowiska akademickie, są one ogłaszane tak, aby wybrać kandydata wstępnie wytypowanego przez społeczność akademicką zgodnie z jej własnymi kryteriami. Kiedy kryteria awansu powiązane są z międzynarodowymi publikacjami, wydział zawiera porozumienie o wzajemnych publikacjach ze swoim czeskim odpowiednikiem. Takie mechanizmy adaptacyjne podkopują niestety zaufanie społeczne będące zasadniczym fundamentem i instytucyjnego, i instrumentalnego modelu pracy akademickiej. Pomimo że cykle perturbacji i kompensacji wyglądają w oczach pracowników naukowych bardziej jak powrót do komunistycznej przeszłości niż droga ku lepszej przyszłości, nie było innego oczywistego sposobu realizacji instrumentalnego wzorca.

Korzenie tego dylematu być może najlepiej wyjaśnić będzie za pomocą metafory. Polski system szkolnictwa wyższego w latach 90. XX w. przypominał rolnika, który musiał zaorać pole, ale nie miał konia. Wobec braku tego, czego potrzebowal, rolnik zaprzągł do pługa swoją mleczną krowę. Krowa wykonała zadanie, ale urazy spowodowane zaprzęgiem miały negatywny wpływ na jej zdrowie i obniżyły jakość jej mleka. W miarę jak gospodarstwo rolnika się rozwijało, konie nadal były trudno dostępne i postanowił zainwestować w więcej krów do orania swoich pól. Dwadzieścia lat 
później konie są już dostępne na rynku, ale rolnik ma już stado krów, które nie produkują dobrego mleka ze względu na urazy spowodowane zaprzęgami, ale radzą sobie z oraniem pól na tyle dobrze, żeby rolnik ledwo utrzymywał swoje gospodarstwo.

We wczesnych latach po transformacji rząd musiał przygotować siłę roboczą do gospodarki rynkowej, ale dysponował niewieloma instytucjami oraz nieliczną kadrą dydaktyczną wyspecjalizowaną do pełnienia tego rodzaju zadań. Miał jednak dostęp do istniejących uniwersytetów i innych ISW. Tożsamości organizacyjne oraz struktury instytucjonalne najbardziej szanowanych jednostek były w przeważającej mierze zorientowane na zupełnie inny rodzaj aktywności niż przygotowanie siły roboczej do gospodarki rynkowej - było to poszukiwanie wiedzy oraz formacja wszechstronnie wykształconych obywateli. System został szybko poszerzony, z rosnącą liczbą instytucji i pracowników naukowych wzorowanych oraz socjalizowanych według organizacyjnego wzorca korespondującego z innymi celami i mitami niż te postawione nagle przed zarówno starymi, jak i nowymi jednostkami. Dwadzieścia lat później pola kształcenia zgodnego z wymaganiami rynku pozostają krzywo zaorane, a produkcja mleka nowej wiedzy jest ograniczana przez urazy spowodowane zaprzęgiem rynku. Wyjątkowy przypadek technicznej ISW umacnia jedynie ten wniosek jedyną placówką w tym badaniu, której żaden z przywódców nie opisał jako „chorej”, jest ta, której zasadnicza tożsamość jest spójna z mitem przyjmowanym przez rząd oraz z celami służby gospodarce. Wracając do metafory rolnika, ta techniczna ISW jest koniem, który być może cierpi z powodu zbyt ciasnego zaprzęgu, ale zaprzęg nie neguje ani nie ogranicza jego zasadniczej tożsamości.

W świetle ustaleń niniejszego badania, jaki jest prawdopodobny wpływ Ustawy 2.o, która posuwa się o krok dalej w instrumentalnej logice, oferując większą autonomię w zamian za sprawozdawczą odpowiedzialność, przy jednoczesnym poluzowaniu regulacyjnego „zaprzęgu”? Podstawa całej reformy, czyli wynagradzanie instytucji wytwarzających wymierną wiedzę, ma większy potencjał połączenia dwóch wizji uniwersytetu niż założenia poprzednich reform. Prowadzenie wysokiej jakości badań poszerzających granice istniejącej wiedzy leży u podstaw tego, co pracownicy naukowi postrzegają jako tożsamość ich instytucji, a jednocześnie jest także cenione pod względem potencjalnej maksymalizacji publicznych zysków. Nowy mechanizm oceny skupiający się na wybranych osiągnięciach już postrzegany jest jako lepszy niż wcześniejsze naciski na wydawanie jak największej ilości publikacji, bez względu na ich rzeczywistą wartość dla badacza. To, czy to połączenie mitów okaże się wykonalne, zależy od tego, jak jednostki akademickie zinterpretują i wdrożą nowe kryteria oceny, przekazując je pracownikom naukowym.

Co więcej, dwoma instytucjami kluczowymi, jeżeli chodzi o obiecujący most pomiędzy dwoma „zracjonalizowanymi mitami” w dziedzinie badań, są agencje finansowania nauk podstawowych i stosowanych: Narodowe Centrum Nauki (NCN) 
oraz Narodowe Centrum Badań i Rozwoju (NCBiR), które okazały się zdolne do zyskania większej legitymizacji niż ich poprzednicy. Ich dalszy sukces w realiach obecnej reformy zależy od społecznego postrzegania zasadności i transparentności metod stosowanych w ocenie merytorycznej wniosków o dofinansowanie. Zależy również od stopnia, w jakim obecny rząd zdecyduje się wydatkować większość funduszy na badania naukowe poprzez niezależne instytucje, a nie kanałami politycznymi.

Jednak w szerszym kontekście, działania obecnego rządu zwiększające jego kontrolę nad sądownictwem, instytucjami kultury oraz mediami publicznymi budzą obawy, że Ustawa 2.o stanowi zawoalowaną próbę zrobienia tego samego ze szkolnictwem wyższym. Fakt, że niezależne agencje wydatkują mniej niż połowę krajowego budżetu przeznaczonego na badania, nie wspomaga budowania zaufania publicznego. Aby Ustawa 2.o utrzymała legitymizację w oczach głównych interesariuszy, działalność dwóch agencji finansujących musiałaby zostać rozszerzona przy uwzględnieniu tego, że wyniki przeprowadzonego przez UNESCO badania wskazują, że kraje o średnich dochodach zazwyczaj odnoszą większą korzyść z badań translacyjnych niż podstawowych (Schaaper 2014).

Jeśli chodzi o cel promowania umiejętności potrzebnych na rynku pracy, nowa ustawa wydaje się skłaniać w stronę wartości społeczności akademickiej, podtrzymując większy prestiż programów oraz dyscyplin akademickich oraz kierując szeroki strumień funduszy w stronę tradycyjnych uniwersytetów. Posunięcie to wydaje się problematyczne jeśli chodzi o kształcenie absolwentów mających duże możliwości zatrudnienia, ponieważ ujęte w niniejszym badaniu uniwersytety wydają się być nosicielami odmiennego „DNA” niż to, które rząd chciałby promować w odniesieniu do dydaktyki. Jednakże, dopóki gospodarka rozwija się dynamicznie dzięki szerokiemu strumieniowi funduszy z Unii Europejskiej, a absolwenci z łatwością wkraczają na „rynek pracownika”, umiejętności zdobyte w instytucjach akademickich będą najprawdopodobniej postrzegane jako wystarczające dla obecnej sytuacji. W związku z tym Prawo 2.0 otwiera tradycyjnym uniwersytetom możliwość dowiedzenia twierdzenia, że krytyczne myślenie, „miękkie umiejętności” i nawyki związane z ustawicznym kształceniem mają w gospodarce XXI w. większe znaczenie niż posiadanie konkretnej umiejętności traktowanej priorytetowo przez pracodawców. Prawo to w żaden sposób nie zachęca jednak do dążenia do tych rezultatów, ponieważ instytucje i poszczególni pracownicy naukowi mają być oceniani tylko w oparciu o wytwarzanie wymiernej wiedzy.

Ostatnia uwaga dotyczy tego, że wpływ Ustawy 2.0 zostanie prawdopodobnie rozmyty przynajmniej po części przez samo tempo zmian legislacyjnych w polskim szkolnictwie wyższym w ciągu ostatnich lat, które to spowodowało silne poczucie „zmęczenia reformami”. Społeczność akademicka z trudem nadąża za nowymi przepisami i zarządzeniami. Każda kolejna reforma pogłębia wrażenie, że poprzednia była 
niekompletna i niedopracowana, a nowe rozwiązania nie otrzymywały możliwości dojrzenia lub wydania owoców, lecz były zastępowane jeszcze nowszymi mechanizmami. Niezależnie od tego, czy spostrzeżenia te odpowiadają rzeczywistości, już samo odnoszone wrażenie zwiększa prawdopodobieństwo, że kolejne reformy spotkają się w najbliższej przyszłości z oburzeniem, omijaniem, a nawet podważaniem ich podstaw.

\section{Wnioski}

Systemy społeczne generują zazwyczaj rezultaty, do których zostały stworzone. Według teoretyka systemów Richarda Buckminstera Fullera „Nigdy nie zmienia się nic poprzez walkę z istniejącą rzeczywistością. Aby coś zmienić, trzeba zbudować nowy model, który uczyni stary nieaktualnym" (Fuller 2019, tłum. własne). Organizacyjne „DNA” nakazujące samoodtwarzanie uniwersytetu jako społecznej instytucji w służbie prawdy pozostaje niezwykle żywotne (Lenartowicz 2015). Fakt ten potwierdzony został wielokrotnie w badaniach obejmujących pracowników naukowych. Hasła bezstronnej prawdy i akademickiej samorządności są okrzykami bojowym pracowników naukowych w Czechach (Pabian et al. 2011), Niemczech (Krucken, 2003; Pritchard, 2004), Włoszech (Tavoletti, 2010), Austrii (Pechar, 2012) i Polsce (Shaw 2018). Jak zauważyły Shaw i Lenartowicz (2016), rządy i reformatorzy, którzy próbują wykuć nową tożsamość dla europejskich uniwersytetów, zmagają się nie tylko z potężną tradycją kojarzoną z Wilhelmem von Humboldtem, ale także z dekadami badań wykazujących, że, ogólnie rzecz biorąc, reformy instytucji szkolnictwa wyższego są niezwykle trudne do wprowadzenia i zazwyczaj kończą się niepowodzeniem (Hotho 2013; Wildavsky et al. 2011; Psacharopoulos 1989; Clark 1986; Levine 1980). Maassen i Olsen (2007) zasugerowali, że reformy w szkolnictwie wyższym odnoszą porażkę wtedy, kiedy sprzeczne logiki instytucjonalne - lub „zracjonalizowane mity" - powodują zamieszanie, spory i bezwład. Wydaje się, że tak właśnie było w przypadku polskich reform z lat 2010-2011, co ilustruje mnogość przykładów wątpliwej wartości zachowań kompensacyjnych dążących do realizacji któregokolwiek zestawu pożądanych celów.

Ustalenia te są sposobnością do kilku słów przestrogi wobec wdrażania polityki naukowej w oparciu o założenie, że historycznie ugruntowaną instytucję uniwersytetu da się przeorientować na narzędzie realizacji państwowych celów za pomocą optymalnej równowagi marchewek i najnowocześniejszych nawet kijów - szczególnie w postkomunistycznym kontekście, gdzie związek pomiędzy narodowym i akademickim samostanowieniem jest wyjątkowo głęboko zakorzeniony. Z perspektywy teorii systemów drugiej fali, reformy o największych szansach powodzenia to nie te, które umiejętnie równoważą kary i nagrody, lecz te, które uderzają we właściwą nutę 
w zasadniczej tożsamości systemu. W opisywanym przypadku wydaje się, że tożsamością instytucjonalną, która ma największą szansę dopasować się do „pożądanych celów" rozwoju społecznego i gospodarczego, jest tożsamość politechniki - uczelni technicznej. Wniosek ten nie jest zaskakujący, jeśli weźmie się pod uwagę profil tej uczelni i jej długoletnie tradycje współpracy z przemysłem. Stwierdzenie to jest spójne z obserwacją Stinchcombe'a (1968) dotyczącą „korelacji pomiędzy czasem w historii, kiedy został stworzony dany typ organizacji, a strukturą społeczną tego typu istniejącą w czasie teraźniejszym" (s. 143, tłum. własne). Tym, co wydaje się zaskakujące, jest „akademicki dryf” zawodowej ISW, instytucji utworzonej w latach 90. XX w. $\mathrm{w}$ celu prowadzenia praktycznego kształcenia, aspirującej jednak do pozbycia się swojego przymiotnika i stania się „normalnym” uniwersytetem. W tym przypadku najprawdopodobniej przewaga kadry akademickiej („kolonii komórek”) importowanej bezpośrednio z tradycyjnej uczelni flagowej spowodowała powielenie wcześniejszego paradygmatu organizacyjnego („DNA”) zamiast stworzenia nowego wzorca.

Z niniejszych badań wynika wniosek, że jeśli konsekwencje odrębnych i żywotnych tożsamości różnych typów ISW nie będą traktowane przez decydentów jako bardzo realne, reforma może zamiast wprowadzenia istotnych zmian wywołać kompensacyjne adaptacje i „zmęczenie reformami”. Co może to oznaczać w praktyce? Jeśli jedyną zmianą wartą publicznych środków jest taka, która przesuwa wzorzec tożsamości wyrażany w codziennym dyskursywnym samoopisie organizacji (Lenartowicz 2018), to najbardziej oczywistym punktem wyjścia byłoby dogłębne zbadanie tożsamości organizacyjnej wyrażanej w codziennej komunikacji jej przedstawicieli. Co więcej, chociaż rezultat w postaci umiejętności i innowacji potrzebnych na rynku pracy był nieobecny w źródłowym modelu tradycyjnych uniwersytetów, z pewnością stanowi on źródłową tożsamość wielu innych instytucji, którym rząd do tej pory nie poświęcał takiej uwagi jak uniwersytetom. W Polsce powstały prywatne ISW, organizacje pozarządowe i fundacje mające na celu wypełnienie tej niszy. Niektóre z nich opracowały wysoce innowacyjne programy edukacyjne zasługujące na publiczne wsparcie. Instytucje takie są przykładami nowych struktur organizacyjnych stworzonych w ciągu ostatnich dwudziestu lat w celu zaspokajania dokładnie tych samych potrzeb, do których realizacji rząd próbował skłonić tradycyjne ISW. Zważywszy na wątpliwe powodzenie wcześniejszych prób, decydenci mogliby rozważyć dywersyfikację publicznych inwestycji w różne typy struktur edukacyjnych spełniające różne funkcje. Nie ulega wątpliwości, że tradycyjne uniwersytety nadal mają swoją rolę do odegrania w poszerzaniu granic wiedzy i formacji szeroko wykształconych elit - to właśnie jest mleko, do którego produkcji zostały stworzone. Być może jednak nadszedł czas, aby przestano od nich wymagać orania pól, jako że istnieją inne typy ISW mające na swoim koncie duże osiągnięcia, które mogłyby się okazać warte publicznych inwestycji. 


\section{Podziękowania}

Autorka wyraża wdzięczność za wsparcie Fundacji na Rzecz Nauki Polskiej (Grant 5./2015: Autonomia instytucjonalna i modele adaptacji polskich uniwersytetów do zmieniającego się otoczenia społecznego i ekonomicznego) oraz pomoc kierownika projektu, prof. Marka Kwieka. Autorka pragnie także podziękować prof. Davidowi Chapmanowi za jego wsparcie w sformułowaniu i przeprowadzeniu niniejszych badań oraz dr Marcie Lenartowicz za zapoznanie z ujęciem teoretycznym autopoiesis.

Załącznik A. System kodowania

P. Code System
+Instrumental Logic
+ Central Maximization of Returns
+ State as advocate for social interest
+ Autonomy in return for accountability

Załącznik B. Wizualne przedstawienie poglądów uczestników

\begin{tabular}{|c|c|c|c|c|c|c|c|c|c|c|c|c|}
\hline Code System & 101 & 102 & 103 & 104 & 105 & 106 & 107 & 108 & 109 & 110 & 111 & 112 \\
\hline $\begin{array}{l}\text { E Ci +Instrumental Logic } \\
\text { § Ci - Critique of Instrumental } \\
\text { Logic }\end{array}$ & • & • & • & • & • & • & • & • & • & • & • & - \\
\hline $\begin{array}{l}\mathrm{S} \mathrm{Ci}^{*} \text { Critique of Institutional } \\
\text { Logic }\end{array}$ & & • & $\bullet$ & ${ }^{\circ}$ & & & & & & & $\bullet^{\circ}$ & \\
\hline
\end{tabular}

Objaśnienie: na rysunkach rozmiar kropek odpowiada liczbie segmentów zakodowanych w danym wywiadzie. Obliczenia rozmiaru symboli odnoszą się do kolumn.

Rysunek B1. Decydenci

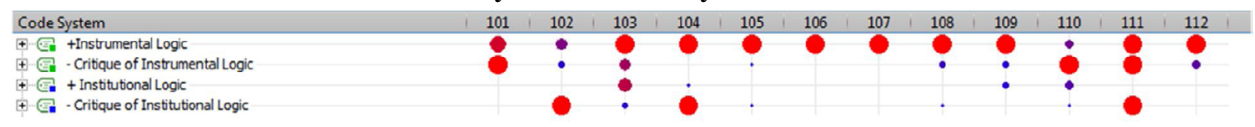

Rysunek B2. Przywódcy akademiccy

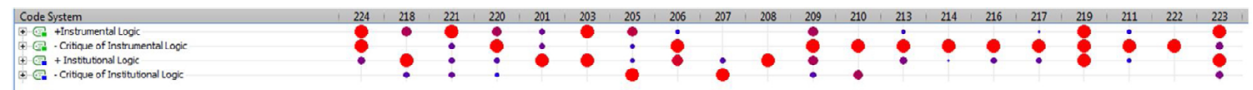




\section{Literatura}

Agasisti, T., Catalano, G. (2006). Governance models of university systems-towards quasi-markets? Tendencies and perspectives: a European comparison. Journal of Higher Education Policy and Management 28 (3), 245-262. https://doi.org/10.1080/13600800600980056.

Bok, D. (2009). Universities in the Marketplace: The Commercialization of Higher Education. Princeton University Press, Princeton, NJ.

Braun, D., Merrien, F.X. (1999). Governance of universities and modernisation of the state: analytical aspects. W: Braun, D., Merrien, F.X. (red.), Towards a New Model of Governance for Universities? Kingsley, London, ss. 9-33.

Capano, G., Regini, M. (2014). Governance reforms and organizational dilemmas in European universities. Comparative Education Review 58 (1), 73-103.

Clark, B.R. (1986). The Higher Education System: Academic Organization in Cross National Perspective. University of California Press, Berkeley, CA.

Dobbins, M., Knill, C. (2009). Higher education policies in Central and Eastern Europe: convergence toward a common model? Governance 22 (3), 397-430.

Dobbins, M. (2011). Higher Education Policies in Central and Eastern Europe: Convergence Towards a Common Model? Palgrave Macmillan, Houndmills, Basingstoke, Hampshire; New York.

Dobbins, M. (2017). Exploring higher education governance in Poland and Romania: re-convergence after divergence? Comparative Education Review 16 (5), 684-704. https:// doi.org/ 10.1177/1474904116684138.

European Social Survey. (2018, January 25). Retrieved January 25, 2018, from http:// www. europeansocialsurvey.org/.

Fuller, B. (n.d.). The countdown begins. Retrieved from https://www.bfi.org/ideaindex/ projects/2015/greenwave.

Geertz, C. (1973). The Interpretation of Cultures. Basic Books.

Gornitzka, A., Maassen, P. (2000). Hybrid steering approaches with respect to European higher education. Journal of Higher Education Policy and Management 13 (3), 267-285.

Gornitzka, A., Maassen, P. (2017). European Flagship universities: autonomy and change. Higher Education Quarterly 71 (3), 231-238. https://doi.org/10.1111/hequ.12130.

Gornitzka, A., Maassen, P., Olsen, J.P., Stensaker, B. (2007). „Europe of Knowledge:”Search for a New Pact. University dynamics and European integration, ss. 181-214.

Heinze, T., Knill, C. (2008). Analysing the differential impact of the Bologna process: theoretical considerations on national conditions for international policy convergence. Higher Education 56 (4), 493-510.

Hotho, S. (2013). Higher education change and its managers: alternative constructions. Educ. Manag. Adm. Leadersh. 41 (3), 352-371. https://doi.org/10.1177/ 1741143212474806. 
Katz, D., Kahn, R.L. (1966). Organizations and the system concept. The Social Psychology of Organizations. John Wiley \& Sons, New York, ss. 14-29.

King, R.P. (2007). Governance and accountability in the higher education regulatory state. Higher Education: Int. J. High. Educ. Educ. Plann. 53 (4), 411-430.

Krucken, G. (2003). Learning the 'New, New Thing': on the role of path dependency in university structures. Higher Education 46 (3), 315-339. https://doi.org/10.1023/ A:1025344413682.

Kulczycki, E. (2017). Assessing publications through a bibliometric indicator: the case of comprehensive evaluation of scientific units in Poland. Res. Eval. 26 (1), 41-52. https://doi.org/10.1093/reseval/rvw023.

Kwiek, M. (2012). Higher education reforms and their socio-economic contexts: shifting funding regimes and competing social narratives. W: Kwiek, M., Maassen, P. (red.), National Higher Education Reforms in a European Context: Comparative Reflections on Poland and Norway. Peter Lang., Bern, ss. 155-176.

Kwiek, M. (2015). The unfading power of collegiality? University governance in Poland in a European comparative and quantitative perspective. Int. J. Educ. Dev. 43, 77-89. https://doi.org/10.1016/j.ijedudev.2015.05.002.

Lenartowicz, M. (2015). The nature of the university. Higher Education 69 (6), 947-961. https://doi.org/10.1007/s10734-014-9815-0.

Lenartowicz, M. (2018). Financing organizational changes from without: a valid instrument or a costly illusion of strategic public policy? J. Account. Organ. Change 14 (1), 99-116. https://doi.org/10.1108/JAOC-12-2016-0083.

Levine, A. (1980). Why Innovation Fails: The Institutionalization and Termination of Innovation in Higher Education. SUNY Press, New York.

Luhmann, N. (2009). Self-organization and autopoiesis. W: Clarke, B., Hansen, M.B.N. (red.), Emergence and Embodiment: New Essays on Second-Order Systems Theory, ss. 143-156.

Maassen, P.A., Olsen, J.P. (red.) (2007). University Dynamics and European Integration. Springer.

Magalhaes, R., Sanchez, R. (2009). Autopoiesis in Organization Theory and Practice. Emerald Group Publishing, Bingley.

Marginson, S. (2018). High participation systems of higher education. W: Cantwell, B., Marginson, S., Smolentseva, A. (red.), High Participation Systems of Higher Education. Oxford University Press, Oxford, ss. 3-38.

Menzel, H. (1978). Meaning: who needs it? W: Brenner, M., Marsh, P., Brenner, M. (red.), The Social Contexts of Method. St. Martin's Press, New York, ss. 140-171.

Meyer, J.W., Rowan, B. (1977). Institutionalized organizations: formal structure as myth and ceremony. Am. J. Sociol. 340-363.

Olsen, J.P. (2007). The institutional dynamics of the European university. W: Maassen, P., Olsen, J.P. (red.), University Dynamics and European Integration. Springer, Dordrecht, ss. 25-53. 
Pabian, P., Sima, K., Kyncilova, L. (2011). Humboldt goes to the labour market: how academic higher education fuels labour market success in the Czech Republic Journal of Education and Work 24 (1-2), 95-118.

Pechar, H. (2012). The decline of an academic oligarchy. The Bologna process and 'Humboldt's last warriors'. W: Curaj, A., Scott, P., Vlasceanu, L., Wilson, L. (red.), European Higher Education at the Crossroads. Springer, Netherlands, ss. 613-630. Retrieved from http://link.springer.com/chapter/10.1007\%2F978-94-007-3937-6_33\#page-1.

Peteri, G. (2000). On the legacy of state socialism in academia. W: David-Fox, M., Peteri, G. (red.), Academia in Upheaval: Origins, Transfers, and Transformations of the Communist Academic Regime in Russia and East Central Europe. Bergin \& Garvey, Westport, CT, ss. 275-302.

Poland (2010). Założenia do nowelizacji ustawy - Prawo o szkolnictwie wyższym oraz ustawy o stopniach naukowych i tytule naukowym oraz o stopniach i tytule w zakresie sztuki. (Proposal of reform to The Act on Academic Degrees and Title and on Degrees and Title in Art of 23rd March 2003.). Ministry of Science and Higher Education, Warsaw.

Poland (2018). Ustawa z dnia 20 lipca 2018 - Prawo o szkolnictwie wyższym i nauce (Statute from 20 July 2018: Law on Higher Education and Science), Pub. L. No. 1668, 1. Retrieved from http://konstytucjadlanauki.gov.pl/content/uploads/2018/o8/ kdn.pdf.

Polish Graduate Tracking System (2018). Retrieved April 4, 2018, from http://ela.nauka. gov.pl/en/.

Pritchard, R. (2004). Humboldtian values in a changing world: staff and students in German universities. Oxford Review of Education 30 (4), 509-528.

Psacharopoulos, G. (1989). Why educational reforms fail: a comparative analysis. Int. Rev. Educ. 35 (2), 179-195. https://doi.org/10.1007/BFoo598437.

Ramirez, F., Tiplic, D. (2014). In pursuit of excellence? Discursive patterns in European higher education research. Higher Education 67 (4), 439-455. https://doi.org/10.1007/ s10734-013-9681-1. 00181560.

Gazeta Wyborcza (2013, październik 1). Rektor UW na inauguracji roku: „Uniwersytet to nie firma" (Rector of Warsaw University at the inauguration:' The university is not a firm'). Retrieved from http://m.warszawa.gazeta.pl/warszawa/1,106541,14706069, Rektor_UW_na_inauguracji_roku_Uniwersytet_to_nie.html.

Schaaper, M. (2014). The case for graduate education: does university-based research really lead to national economic development? Montreal W: Chapman, D.W., Chien, C.-L. (red.), Higher Education in Asia: Expanding Out, Expanding up. UNESCO Institute for Statistics, Montreal, ss. 49-64.

Schriewer, J. (2009). „Rationalized myths” in European higher education: the construction and diffusion of the bologna model. Eur. Educ. 41 (2), 31-51. 
Schwandt, T.A. (2000). Three epistemological stances in qualitative inquiry: inter-pretivism, hermeneutics, social constructivism. W: Denzin, N.K., Lincoln, Y.S. (red.), Handbook of Qualitative Research, 2nd ed. Sage, Thousand Oaks, CA, ss. 189-213.

Seidl, D. (2016). Organisational Identity and Self-Transformation: An Autopoietic Perspective. Routledge.

Shaw, M.A. (2018). Public accountability versus academic independence: tensions of public higher education governance in Poland. Studies in Higher Education. https://doi.org/10.1080/03075079.2018.1483910.

Shaw, M.A., Lenartowicz, M. (2016). Humboldt is (not) dead: A social systems perspective on reforming European universities. W: Wie Bildung organisiert wird (red.), Soziologische Analysen zu Schule, Berufsbildung, Hochschule und Weiterbildung. (How education gets organized: Sociological analyses of schools, vocational, higher, and continuing education). BeltzJuventa Verlag, Weinheim/Munchen, ss. 272-274.

Simonova, N., Antonowicz, D. (2006). Czech and polish higher education-from bureaucracy to market competition. Czech Sociological Review 42 (3), 517-536.

Stinchcombe, A. (1968). Social structure and organizations. W: March, J. (red.), Handbook of Organizations. Rand McNally, Chicago, ss. 142-193.

Sztompka, P. (1993). Civilizational incompetence: the trap of post-communist societies. Z. Soziol. 22 (2), 85-95.

Tavoletti, E. (2010). Matching higher education with the labour market in the knowledge economy: the much-needed reform of university governance in Italy. Ind. High. Educ. 24 (5), 361-375 https://doi.org/Article.

Thomas, W.I., Znaniecki, F. (1927). The Polish Peasant in Europe and America. Alfred A. Knopf, New York.

Trakman, L. (2008). Modelling university governance. Higher Education Quarterly 62 (1-2), 63-83. https://doi.org/10.1111/j.1468-2273.2008.00384.x.

Von Bertalanffy, L. (1968). General System Theory: Foundations, Development, Applications. George Braziller, Inc., New York.

Wildavsky, B., Kelly, A.P., Carey, K. (2011). Reinventing Higher Education: The Promise of Innovation. Harvard University, G.S. of E. Harvard Education Press.

World Bank (2017). World Development Indicators. Dostęp: styczeń 29, 2018, z https:// data.worldbank.org/data-catalog/world-development-indicators.

Zha, Q. (2009). Diversification or homogenization in higher education: a global allomorphism perspective. Higher Education in Europe 34 (3-4), 459-479.

Zysiak, A. (2016). Punkty za pochodzenie: Powojenna modernizacja i uniwersytet $w$ robotniczym mieście (Points for social background: Post-war modernization and the university in a working-class city). Nomos, Kraków. 


\title{
Strategic instrument or social institution: Rationalized myths of the university in stakeholder perceptions of higher education reform in Poland
}

\begin{abstract}
European universities have come under reform pressures to make them instruments of social and economic development, compromising their earlier status as socially buffered institutions. The aim of this paper was to investigate the hypothesis that tensions and inconsistencies in recent higher education reforms in Poland trace back to a fundamental conflict between institutional and instrumental visions of the university. Findings suggest an intersection of "rationalized myths” that locks the university sector in a „corset” experienced by stakeholders more like a return to the Soviet past than the way of a better future. Seen through the lens of second-order systems theory, these findings problematize the assumption that the historically grounded institution of the university can be re-oriented as an instrument for achieving state priorities with a mere balance of carrots and state-of-the-art sticks.
\end{abstract}

KEYWORDS: Educational Policy, Educational Reform, European Universities, University Autonomy, Higher Education Governance, Autopoiesis, Systems Theory

CYTOWANIE: Marta, S. (2019). Strategiczny instrument czy instytucja społeczna? Zracjonalizowane mity uniwersytetu w percepcjach interesariuszy reform szkolnictwa wyższego w Polsce. Nauka i Szkolnictwo Wyższe. 1-2(53-54): 251-287. DOI: 10.14746/nisw.2019.1-2.8.

MARTA SHAW - wykłada w Instytucie Spraw Publicznych UJ i Bethel University w USA, gdzie zajmuje się teorią organizacji, zarządzaniem międzykulturowym i przywództwem w edukacji. Przez ostatnią dekadę badała wpływ globalizacji na zarządzanie i przywództwo w edukacji, kolejny rozdział jej badań dotyczy implikacji zrozumienia człowieka jako zwierzęcia nie racjonalizującego lecz racjonalizującego na teorię i praktykę zarządzania w Antropocenie.

E-mail: marta.shaw@uj.edu.pl 